\title{
Profielschets bijstandsontvangers Heerlen
}

Citation for published version (APA):

Künn, A., Poulissen, D., \& de Grip, A. (2020). Profielschets bijstandsontvangers Heerlen: Complexiteit van de problematiek en reïntegratiekansen. ROA. ROA Reports No. 003

https://doi.org/10.26481/umarep.2020003

Document status and date:

Published: 16/12/2020

DOI:

10.26481/umarep.2020003

Document Version:

Publisher's PDF, also known as Version of record

\section{Please check the document version of this publication:}

- A submitted manuscript is the version of the article upon submission and before peer-review. There can be important differences between the submitted version and the official published version of record.

People interested in the research are advised to contact the author for the final version of the publication, or visit the DOI to the publisher's website.

- The final author version and the galley proof are versions of the publication after peer review.

- The final published version features the final layout of the paper including the volume, issue and page numbers.

Link to publication

\footnotetext{
General rights rights.

- You may freely distribute the URL identifying the publication in the public portal. please follow below link for the End User Agreement:

www.umlib.nl/taverne-license

Take down policy

If you believe that this document breaches copyright please contact us at:

repository@maastrichtuniversity.nl

providing details and we will investigate your claim.
}

Copyright and moral rights for the publications made accessible in the public portal are retained by the authors and/or other copyright owners and it is a condition of accessing publications that users recognise and abide by the legal requirements associated with these

- Users may download and print one copy of any publication from the public portal for the purpose of private study or research.

- You may not further distribute the material or use it for any profit-making activity or commercial gain

If the publication is distributed under the terms of Article $25 \mathrm{fa}$ of the Dutch Copyright Act, indicated by the "Taverne" license above, 
Maastricht University

\section{Profielschets bijstandsontvangers Heerlen} Complexiteit van de problematiek en reïntegratiekansen

Annemarie Künn-Nelen

Davey Poulissen

Andries de Grip

\section{ROA Rapport}

ROA-R-2020/3

Researchcentrum voor Onderwijs en Arbeidsmarkt | ROA Research Centre for Education and the Labour Market / ROA 


\title{
Colofon
}

(c) Researchcentrum voor Onderwijs en Arbeidsmarkt (ROA). Niets uit deze uitgave mag op enige manier worden verveelvoudigd zonder voorafgaande schriftelijke toestemming van de directeur van het ROA.

\author{
Researchcentrum voor Onderwijs en Arbeidsmarkt \\ Postbus 616 \\ 6200 MD Maastricht \\ $\mathrm{T}+31433883647$ \\ $\mathrm{F}+31433884914$ \\ secretary-roa-sbe@maastrichtuniversity.nl \\ www.roa.nl \\ School of Business and Economics \\ Maastricht University \\ Vormgeving \\ ROA secretariaat, Maastricht
}

ISBN: 978-90-5321-593-7

ISSN: 2666-8858

december 2020

\section{HLIMBURG}

Dit rapport is een onderdeel van het meerjarenprogramma 4 Limburg dat een bijdrage wil leveren om de Limburgse samenleving meer duurzaam, vitaal en inclusief te maken. Het doel van dit programma is om, in nauwe samenwerking met de Universiteit Maastricht, Provincie Limburg en ketenpartners zoals gemeenten, UWV en bedrijfsleven, via een trendbreuk de arbeidsparticipatie én de vitaliteit in Limburg naar een hoger niveau te tillen. 


\section{Inhoud}

Voorwoord

V

Samenvatting

vii

$1 \quad$ Inleiding

2 Overzicht bijstandsontvangers in Heerlen

3 Profielschets van de gemeente Heerlen ten opzichte van andere Limburgse gemeenten

4 Verschillen in de profielen van bijstandsontvangers tussen de wijken in Heerlen

5 Profielschets van bijstandsontvangers en niet-bijstandsontvangers op wijkniveau in Heerlen

6 Ongelijkheid in problematiek onder bijstand- en niet-bijstandsontvangers

7 Profiel van de bijstandsontvangers en de kans op reïntegratie

8 Complexiteit van de problematiek van de bijstandsontvangers en de kans op reïntegratie

9 Conclusie

Bijlage A 


\section{Voorwoord}

Enige tijd geleden werd gemeente Heerlen benaderd door het ROA met het aanbod om de profielschets uitkeringsafhankelijke inwoners in Limburg te vertalen naar de situatie in Heerlen. Op dit aanbod zijn wij uiteraard ingegaan. Dit soort onderzoek vormt een belangrijk onderdeel van de totale monitoring op het gebied van re-integratie en past volledig in het doel van Heerlen om meer datagedreven te werken en sturen.

\section{Problematiek Heerlen}

Heerlen is een stad die haar problemen kent op sociaaleconomisch vlak (werkloosheid, armoede, schulden). Deze problematiek is ontstaan na de sluiting van de mijnen. Hierdoor zijn in de regio 75.000 banen verloren gegaan. Het aantal personen uit de beroepsbevolking in de bijstand bedraagt op dit moment $8,4 \%$ tegenover een landelijk gemiddelde van $4,2 \%$.

\section{Helder beeld}

Het ROA onderzoek geeft ons opnieuw een helder beeld van hoe de zaken er in Heerlen voor staan. Dat Heerlen relatief veel inwoners heeft met financiële problemen wisten we wel, dit onderzoek laat met name zien dat financiële problemen de belangrijkste belemmering vormen voor mensen om duurzaam uit te stromen uit de bijstand. Dit gegeven vormt dan ook een speerpunt van onze aanpak.

\section{Gerichte aanpak in Heerlen-Noord}

Het signaal dat er grote verschillen zijn tussen de diverse buurten en stadsdelen helpt ons bij het opzetten van een gerichte aanpak in Heerlen-Noord. Er wordt gestart in het stadsdeel Hoens-broek. Blijkt de aanpak succesvol, dan wordt deze uitgerold in Heerlen. Dit doen we zoveel als mogelijk samen met (reguliere) werkgevers, onze partners in de re-integratieketen en de hulpverlening in de buurt. We kijken daarbij naar de behoeften van bedrijven en organisaties in deze omgeving. Op die manier hopen we, dat mensen beter voorbereid op de arbeidsmarkt komen en daar duurzaam kunnen blijven. De input van ROA is hierbij erg waardevol.

\section{Samen werken}

Werk staat in Heerlen altijd voorop. Daarom werken we nauw samen met WerkvoorHeerlen en Werkgeversservicepunt Parkstad aan de ontwikkeling van mensen, die zelfstandig (nog) niet in staat zijn een plek op de arbeidsmarkt te veroveren. Door de impact van Covid-19 zetten we bijvoorbeeld meer dan ooit in op scholing en omscholen. Hierbij kijken we naar de competenties van mensen en naar wat ze wél kunnen in plaats van naar de belemmeringen die ze ervaren. 
Ook hierbij geeft de profielschets van ROA ons inzichten en handvatten, waarmee we voortvarend aan de slag kunnen.

\section{Martin de Beer}

Wethouder Economie, Arbeidsmarkt en Sport 


\section{Samenvatting}

Dit rapport is een pilotstudie om te komen tot een beleidstool voor een wijkgericht reïntegratiebeleid voor de bijstandsontvangers in gemeenten. Het rapport geeft een profielschets van de bijstandsontvangers in de verschillende wijken in de gemeente Heerlen. In deze profielschets is op wijkniveau in kaart gebracht in hoeverre bijstandsontvangers te maken hebben met gezondheidsproblemen, financiële problemen, een nietwesterse migratieachtergrond en in hoeverre zij deel uitmaken van een éénoudergezin. Vervolgens is bekeken wat de relatie is tussen de profielkenmerken en de complexiteit van de problematiek met de kans op reïntegratie.

Een aantal belangrijke bevindingen van het rapport:

- Bijstandsontvangers in Heerlen hebben het meest te maken met financiële problemen. Dit betreft een huishoudinkomen onder de armoedegrens, schulden van minimaal 10.000 Euro of een schuldsaneringstraject (Tabel 2). Ook gezondheidsproblemen komen relatief veel voor (Tabel 2).

- Tussen wijken zijn er grote verschillen in de mate waarin bijstandsontvangers te maken hebben met financiële en gezondheidsproblemen. Dit pleit voor een wijkgerichte aanpak van deze problematiek (Tabel 2).

- Voor vrijwel alle wijken in Heerlen geldt dat er onder bijstandsontvangers sprake is van een zeer complexe problematiek (Figuur 12).

- Onze bevindingen bevestigen dat beleid niet in kolommen gevoerd moet worden, maar dat er rekening gehouden moet worden met de multiproblematiek waarmee mensen te maken hebben.

- Alle onderzochte profielkenmerken hangen samen met een lagere kans om duurzaam en volledig te reïntegreren. Dit geldt het sterkst voor financiële problemen en gezondheidsproblemen (Tabel 4).

- Alleen bijstandsontvangers uit een éénoudergezin hebben juist een grotere kans om bijna twee jaar later werkzaam te zijn, maar dit geldt alleen voor werk met behoud van een uitkering (Tabel 4).

- Bijstandsontvangers waarop slechts één aspect van toepassing is, hebben ongeveer $20 \%$ minder kans om te reïntegreren dan bijstandsontvangers waarop geen enkel aspect van toepassing is. Dit geldt ook voor de kans om bijna twee jaar later duurzaam en volledig gereïntegreerd te zijn (Tabel 5). Daarom is het van groot belang om in te zetten op het verminderen van de financiële- en gezondheidsproblemen van bijstandsontvangers.

- Dit geldt ook voor de kans om bijna twee jaar later duurzaam en volledig gereïntegreerd te zijn. Bijstandsontvangers waarvoor alle vijf de aspecten van toepassing zijn hebben ten opzichte van bijstandsontvangers zonder problemen bijna twee 
jaar later ruim twee keer zo weinig kans op werk dan bijstandsontvangers waarvoor slechts één aspect van toepassing is. Dit geldt ook voor de kans om duurzaam en volledig te reïntegreren (Tabel 5).

- Het onderzoek laat zien dat als bijstandsontvangers met complexe problematiek de horde om werk te vinden eenmaal genomen hebben, hun complexe problematiek minder nadelig is voor het behoud van werk zonder aanvullende uitkering (Tabel 6). Dit betekent dat ook bijstandsontvangers met complexe problematiek aangemoedigd en gefaciliteerd moeten worden om aan het werk te gaan.

- Bijstandsontvangers met financiële problemen hebben een beduidend kleinere kans op (duurzame en volledige) reïntegratie. Of er naast deze financiële problemen ook nog sprake is van gezondheidsproblemen, doet er voor de (duurzame en volledige) reïntegratiekansen nauwelijks toe. Alleen als mensen met financiële problemen ook laagopgeleid zijn daalt de kans op reïntegratie weer sterk. Dit is overigens niet het geval voor een duurzame en volledige reïntegratie (Tabel 6).

- Gezien het hoge percentage bijstandsontvangers met financiële problemen en de sterke relatie tussen het hebben van financiële problemen en iemands reïntegratiekansen, lijken financiële problemen de belangrijkste horde voor de reïntegratie van bijstandsontvangers.

- Een goede wijkgerichte aanpak richt zich op het verminderen van die problemen die relatief veel voorkomen onder bijstandsontvangers in de verschillende wijken. 


\section{Inleiding}

In 2019 is er een factsheet gepubliceerd waarin de omvang van de risicogroepen in de Limburgse gemeente Heerlen op 31 december 2017 in kaart is gebracht.' De gemeente Heerlen telde op 31 december 2017, 58.474 inwoners die tot de potentiële beroepsbevolking behoorden én op 31 december 2015 reeds in Nederland woonachtig waren. ${ }^{2}$ Dat wil zeggen dat zij, gezien hun leeftijd, in principe actief zouden kunnen zijn op de arbeidsmarkt. ${ }^{3}$ Een deel van deze inwoners bevindt zich echter in een risicopositie omdat zij uitkeringsafhankelijk en/of niet actief zijn op de arbeidsmarkt.

In dit rapport gaan wij specifiek in op de inwoners met een bijstandsuitkering. Gemeenten hebben immers de verantwoordelijkheid om deze mensen weer naar werk te geleiden. We doen dit door een profielschets te geven van de bijstandsontvangers in de verschillende wijken van Heerlen. Ook hierbij geldt dat we uitgaan van de situatie in december 2017. We gaan voor de profielschets in op vier aspecten die het moeilijker kunnen maken om op de arbeidsmarkt te reintegreren: financiële situatie, gezondheidsproblemen, niet-Westerse migratieachtergond en éénoudergezin. ${ }^{4}$ Wederom rapporteren we op het niveau van de wijken.

Mensen worden geclassificeerd als mensen met financiële problemen als zij wonen in een gezin dat een huishoudinkomen heeft onder de armoedegrens, als zij meer dan 10.000 Euro schuld hebben of als zij een schuldsaneringstraject volgen. Er wordt gesproken van gezondheidsproblemen als iemand medicatie gebruikt in verband met een chronische ziekte, of als iemand door het UWV geclassificeerd is als gedeeltelijk arbeidsongeschikt. ${ }^{5}$ We hebben bepaald of iemand een niet-Westerse migratieachtergond heeft op basis van het geboorteland van van de persoon zelf en van zijn of haar ouders. Ook brengen we in kaart of iemand deel uitmaakt van een éénoudergezin, dat wil zeggen één volwassene met minimaal één (eigen) kind onder de 18 jaar.

1 Künn \& Poulissen (2019) Omvang risicogroepen in de Limburgse gemeente Heerlen, ROA-F-2019-3/Heerlen: https://cris.maastrichtuniversity.nl/en/publications/omvang-risicogroepen-in-de-limburgse-gemeente-heerlen

2 Mensen die tussen 31 december 2015 en 31 december 2017 geïmmigreerd zijn vallen dus buiten het bereik van deze factsheet. Dat geldt ook voor deze notitie. Deze toevoeging wordt in de rest van de notitie niet herhaald.

3 De potentiële beroepsbevolking wordt door ons gedefinieerd als alle inwoners in de leeftijd 15 tot en met 67 jaar.

4 Op het niveau van de wijken bleek het niet haalbaar om het opleidingsniveau van inwoners mee te nemen. Het opleidingsniveau wordt immers voor een deel van de populatie (de oudere cohorten) steekproefsgewijs vastgesteld (https://www.cbs.nl/nl-nl/onze-diensten/maatwerk-en-microdata/microdata-zelf-onderzoekdoen/microdatabestanden/hoogsteopltab-hoogst-behaald-gevolgd-opleidingsniveau). Hierdoor zijn er op wijkniveau te weinig observaties om betrouwbare cijfers te geven.

5 De indeling van medicamenten naar chronische ziektes is gebaseerd op onderzoek van Van Ooijen et al. (2020). Van Ooijen, Alessie, \& Knoef (2020). Measurement and modeling of health over the life cycle, in memio 
In Hoofdstuk 2 laten we allereerst het percentage bijstandsontvangers in Heerlen en de onderliggende wijken zien en vergelijken dit met een aantal referentieregio's. In Hoofdstuk 3 geven we voor alle vier aspecten van de profielschets de relatieve positie van bijstandsontvangers in de gemeente Heerlen weer ten opzichte van de andere Limburgse gemeenten. Ook laten we de relatieve positie van bijstandsontvangers met betrekking tot het opleidingsniveau zien, en brengen we de complexiteit van de problematiek van bijstandsontvangers in kaart. In Hoofdstuk 4 geven we een overzicht waarin de relatieve positie van de bijstandsontvangers in de verschillende wijken in beeld wordt gebracht. In Hoofdstuk 5 vergelijken we de profielschets van mensen in de bijstand met die van mensen die geen bijstandsuitkering ontvangen. In Hoofdstuk 6 wordt vervolgens ingegaan op de ongelijkheid binnen de wijken tussen de profielkenmerken van de mensen met en zonder een bijstandsuitkering. In Hoofdstuk 7 analyseren we in hoeverre de verschillende profielkenmerken samenhangen met de kans op reïntegratie en in Hoofdstuk 8 laten we zien hoe de complexiteit van de problematiek samenhangt met reïntegratiekansen. Ten slotte wordt in Hoofdstuk 9 een overzicht gegeven van de belangrijkste uitkomsten en de implicaties voor het gemeentelijk beleid. 


\section{Overzicht bijstandsontvangers in Heerlen}

In dit hoofdstuk geven we eerst een overzicht van de absolute en relatieve omvang van de totale groep inwoners van de gemeente Heerlen met een bijstandsuitkering. Ook laten we met behulp van een kaartje van de gemeente Heerlen zien hoe groot de verschillen zijn in het aandeel bijstandsontvangers in de verschillende wijken. Zowel Tabel 1 als Figuur 1 zijn overgenomen uit de eerdergenoemde factsheet. ${ }^{6}$

Tabel 1

Overzicht van de absolute en relatieve omvang van inwoners met een bijstandsuitkering

\begin{tabular}{|l|r|r|r|}
\hline & $\begin{array}{r}\text { Aantal inwoners met een } \\
\text { bijstandsuitkering }\end{array}$ & $\begin{array}{r}\text { Aantal inwoners } \\
\text { behorend tot } \\
\text { de potentiële } \\
\text { beroepsbevolking }\end{array}$ & $\begin{array}{r}\text { Inwoners met een } \\
\text { bijstandsuitkering } \\
\%\end{array}$ \\
\hline Gemeente Heerlen & 4.913 & 58.474 & 8,4 \\
\hline Noord-Limburg & 6.296 & 187.721 & 3,4 \\
\hline Midden-Limburg & 4.873 & 157.217 & 3,1 \\
\hline Zuid-Limburg & 19.344 & 395.604 & 4,9 \\
\hline Limburg totaal & 30.513 & 740.542 & 4,1 \\
\hline Nederland totaal & 479.069 & 11.460 .361 & 4,2 \\
\hline Bron: ROA
\end{tabular}

Bron: ROA, berekeningen op basis van microdata van het CBS (eerder gepubliceerd in ROA-F2019-3/Heerlen)

6 Künn \& Poulissen (2019). Omvang risicogroepen in de Limburgse gemeente Heerlen, ROA-F-2019-3/Heerlen: https://cris.maastrichtuniversity.nl/en/publications/omvang-risicogroepen-in-de-limburgse-gemeenteheerlen 


\section{Figuur 1}

Percentage inwoners met een bijstandsuitkering naar de wijk in de gemeente Heerlen

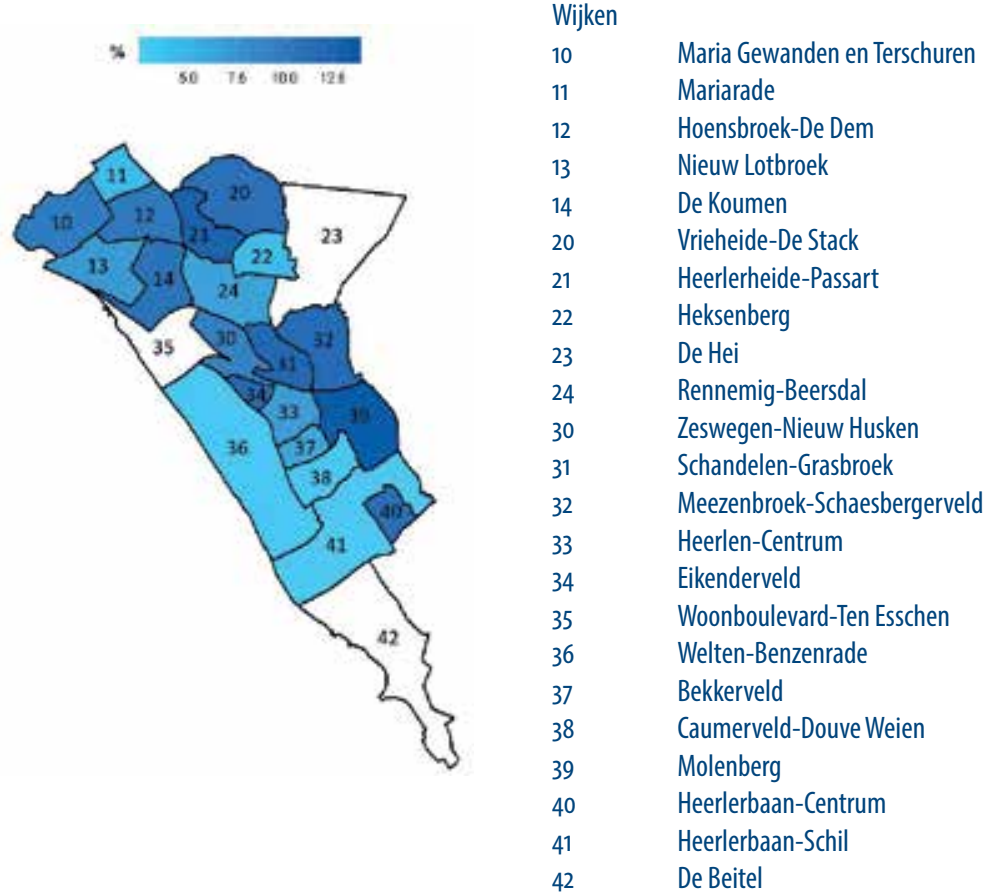

Bron: ROA, berekeningen op basis van microdata van het CBS (eerder gepubliceerd in ROA-F2019-3/Heerlen)

Noot: de wijknummering is gebaseerd op de CBS-wijkcodering

Binnen de gemeente Heerlen zijn er tussen de wijken duidelijke verschillen te zien in het percentage inwoners met een bijstandsuitkering. In de wijken Molenberg, Heerlerheide-Passart en Schandelen-Grasbroek is het percentage bijstandsontvangers het hoogst?

$7 \quad$ Tabel $A_{1}$ in de bijlage geeft een ranking van de wijken in de gemeente Heerlen met betrekking tot het percentage inwoners in de bijstand. 


\section{Profielschets van de gemeente Heerlen ten opzichte van andere Limburgse gemeenten}

In de Figuren 2-5 is te zien wat de relatieve positie is van de bijstandsontvangers in de gemeente Heerlen ten opzichte van de bijstandsontvangers in de andere Limburgse gemeenten. ${ }^{8}$ Daarbij kijkt Figuur 2 naar de financiële situatie, Figuur 3 naar de gezondheidssituatie, Figuur 4 naar het al dan niet hebben van een niet-westerse migratieachtergond en Figuur 5 naar het deel uitmaken van een éénoudergezin. Voor elke gemeente is het percentage bijstandsontvangers gerapporteerd dat te maken heeft met het desbetreffende profielkenmerk. Hoe donkerder de arcering, hoe groter de relatieve problemen voor de mensen in de bijstand.

8 Deze figuren zijn overgenomen uit Künn-Nelen, Poulissen \& De Grip (2020). Profielschets uitkeringsafhankelijke inwoners in Limburg, ROA-F-2020/5: https://cris.maastrichtuniversity.nl/en/publications/profielschetsuitkeringsafhankelijke-inwoners-in-limburg 
Figuur 2

Relatieve positie van gemeenten op het gebied van gezondheidsproblematiek onder mensen in de bijstand

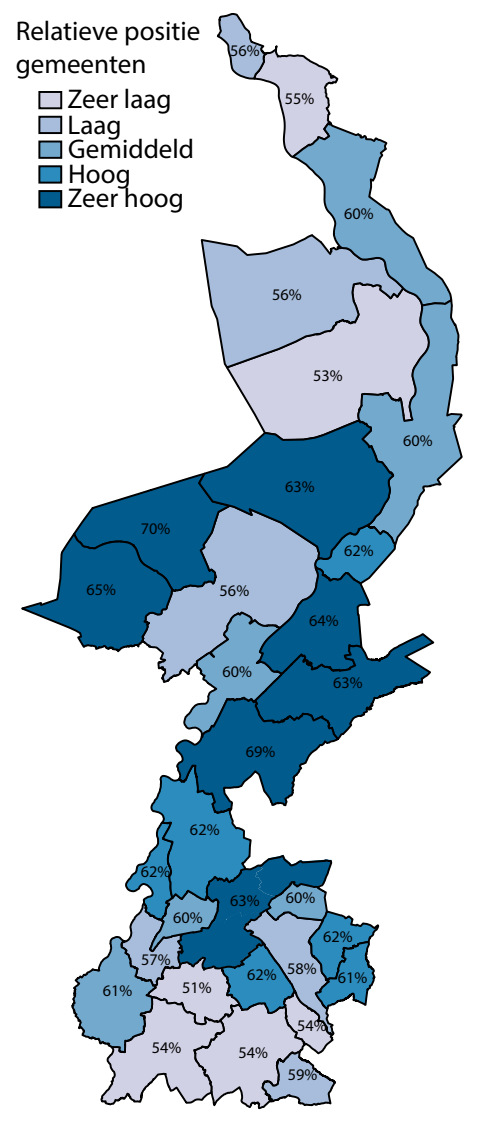

Bron: ROA, berekeningen op basis van microdata van het CBS (eerder gepubliceerd in ROA-F-2020/5)

\section{Figuur 3}

Relatieve positie van gemeenten op het gebied van gezondheidsproblematiek onder mensen in de bijstand

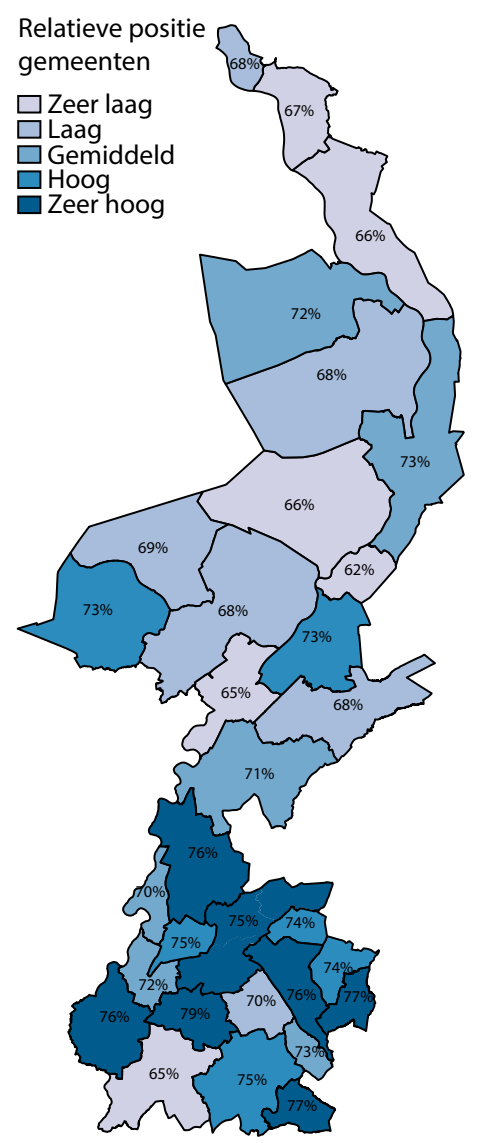

Bron: ROA, berekeningen op basis van microdata van het CBS (eerder gepubliceerd in ROA-F-2020/5) 


\section{Figuur 4}

Relatieve positie van gemeenten op het gebied van niet-westerse migratieachtergrond onder mensen in de bijstand

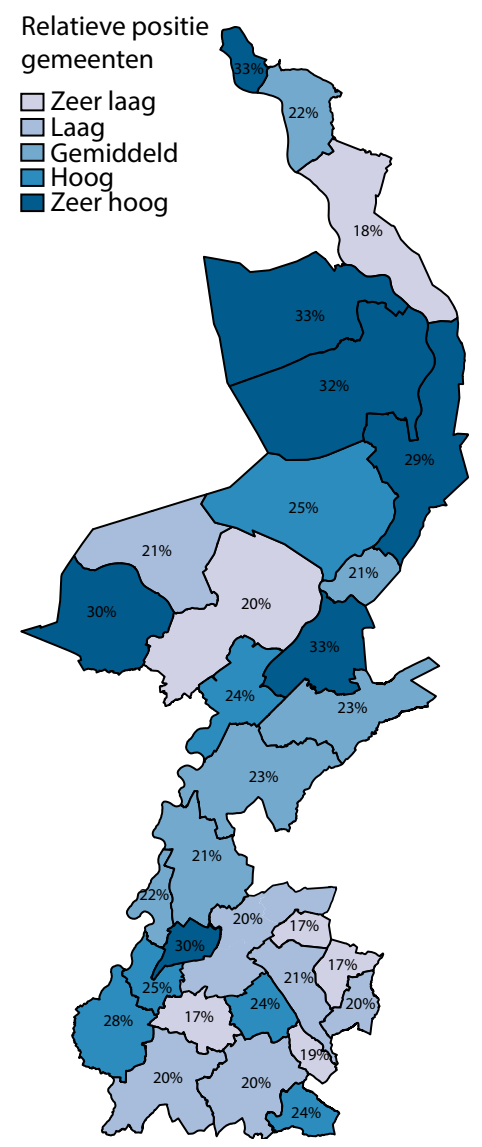

Bron: ROA, berekeningen op basis van microdata van het CBS (eerder gepubliceerd in ROA-F-2020/5) 
In de gemeente Heerlen komen gezondheidsproblemen voor bij 58\% van de mensen in de bijstand. Hoewel dit een hoog percentage is, is het percentage veel lager dan in de meeste andere Limburgse gemeenten.

Tijdens gesprekken met respondenten in het kwalitatieve onderzoek bleek dat zij veel gezondheidsproblemen hebben. Echter, zij spraken voornamelijk over mentale problemen. Deze worden niet veroorzaakt door de uitkeringssituatie, maar wel versterkt. Zo ervaren alle respondenten zowel veel stress rondom de aanvraag: "Het was voor mij destijds een heel stressvolle situatie" $\left(\mathrm{H}_{3}\right)$ als rondom de gesprekken met consulenten "Want als ik moet bellen, dan heb ik een stukje angst... of ik ben dan al zodanig over mijn grens heen dat ik gewoon bang ben dat ik ga flippen zeg maar" $(\mathrm{H} 7)$.

Stress uit zich zowel fysiek als mentaal: "Ik wil graag werken, maar ik heb vaak zoveel aan mijn hoofd en dat je dan ook lichamelijke klachten, dat je eigenlijk niet fatsoenlijk kunt werken" ( $\left.\mathrm{H}_{4}\right)$. "Bij mij zijn het ook gezondheidsfactoren, zeg maar in de zin van mentaal. Het blijkt allemaal mentaal, ja als ik niet lekker in mijn vel zit, dan slaat het ook uit op mijn lichaam" $\left(\mathrm{H}_{7}\right)$.

Door verschillende respondenten werd de wens geuit om minder druk te leggen op het vinden van werk, met meer (geestelijke) ondersteuning. $\mathrm{Er}$ heerst nu het gevoel "Je moet het toch zelf doen" $\left(\mathrm{H}_{3}\right)$ bij de respondenten met een uitkering, wat ze niet als bevorderlijk zien voor herstel van hun mentale gezondheid.

Bron: Schrijver, Bruinsma-Muller \& Stoffers (2020) ${ }^{9}$

Dit is in tegenstelling tot de financiële problematiek waarmee bijstandsontvangers te maken hebben. De gemeente Heerlen scoort hier juist zeer hoog vergeleken met de andere gemeenten: ruim drie kwart van de bijstandsontvangers in Heerlen heeft te maken met een huishoudinkomen onder de armoedegrens, schulden boven de 10.000 Euro en/of deelname aan een schuldsaneringstraject.

Uit het kwalitatief onderzoek kwam naar boven dat veel mensen in de bijstand moeite hebben met rondkomen. Respondenten met een uitkering geven aan dat ze na aanvraag twee maanden hebben gewacht op het ontvangen van een uitkering: "lk heb mijn hele spaargeld moeten opmaken om van te kunnen leven, maar ik kan me voorstellen dat er een heleboel mensen zijn die dat niet hebben en dan gauw schulden opbouwen" $\left(\mathrm{H}_{2}\right)$.

Het tijdig en volledig aanleveren van alle documenten wordt gezien als complex, zeker voor mensen met een laag opleidingsniveau en/of psychische problematiek, terwijl de gevolgen, te weten korting op de Research. Deze volledige bronvermelding wordt niet herhaald bij de volgende tekstboxen. 
uitkering of het opleggen van een boete, lastig op te vangen zijn door het gebrek aan financiële reserves.

Bron: Schrijver, Bruinsma-Muller \& Stoffers (2020)

De gemeente Heerlen is overigens geen uitzondering tussen de Zuid-Limburgse gemeenten. Bijstandsontvangers in de Zuid-Limburgse gemeenten hebben over het algemeen (zeer) veel financiële problemen vergeleken met bijstandsontvangers in andere Limburgse gemeenten.

Ongeveer één op de vijf bijstandsontvangers in Heerlen heeft een niet-westerse migratieachtergrond. Dit is laag vergeleken met de percentages in andere Limburgse gemeenten. Het percentage bijstandsontvangers dat deel uitmaakt van een éénoudergezin is daarentegen in Heerlen met $16 \%$ relatief zeer hoog. Dit geldt overigens ook voor de omringende gemeenten Voerendaal, Brunssum en Landgraaf.

Figuur 6 is een vergelijkbare kaart met betrekking tot het opleidingsniveau van de bijstandsontvangers. Voor elke gemeente is het percentage bijstandsontvangers met maximaal een vmbo diploma weergegeven. Voor Heerlen is dit $56 \%$, wat gemiddeld is vergeleken met de andere Limburgse gemeenten.

Vervolgens is bekeken in hoeverre de bijstandsontvangers in de gemeente Heerlen vaker of minder vaak te maken hebben met meerdere reïntegratie belemmerende factoren dan debijstandsontvangers in andere Limburgse gemeenten. Daarbij is gebruik gemaakt van een complexiteitsindex van de problematiek op gemeenteniveau. De index is een optelsom van het aantal reïntegratie belemmerende factoren waarop een gemeente een (zeer) hoge relatieve positie heeft. Daarbij wordt een onderscheid gemaakt tussen geringe problematiek (geen factoren met een relatief (zeer) hoge positie), enkelvoudige problematiek (één factor met een relatief (zeer) hoge positie), meervoudige problematiek (twee of drie factoren met een relatief (zeer) hoge positie) en zeer complexe problematiek (vier of vijf factoren met een relatief (zeer) hoge positie). In Figuur 7 wordt deze typering in kaart gebracht. In Heerlen is er onder de mensen in de bijstand sprake van een meervoudige problematiek. Deze is opgebouwd uit relatief veel financiële problemen en het relatief vaak deel uitmaken van een éénoudergezin. 
Figuur 5

Relatieve positie van gemeenten op het gebied van éénoudergezin onder mensen in de bijstand

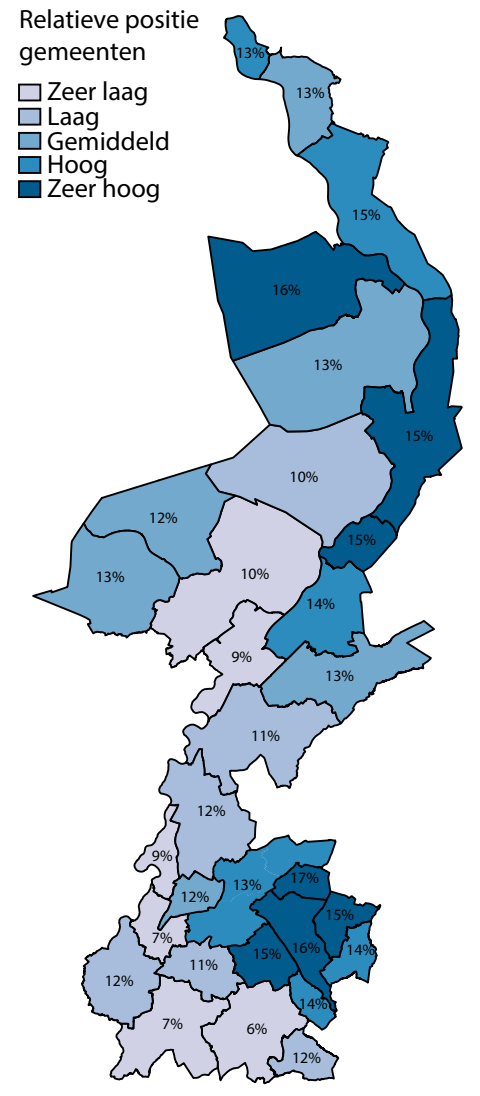

\section{Figuur 6}

Relatieve positie van gemeenten op het gebied van laag opleidingsniveau onder mensen in de bijstand

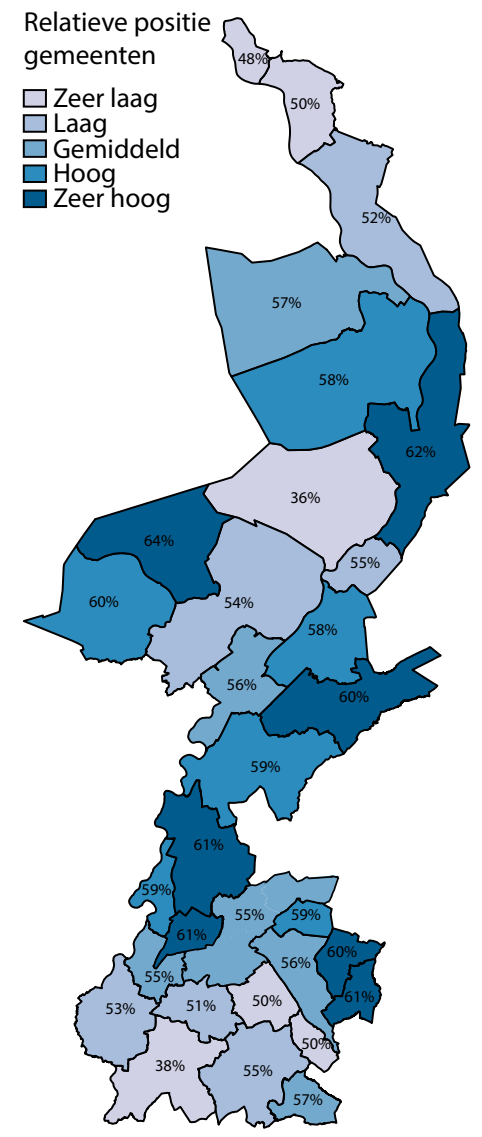

Bron: ROA, berekeningen op basis van microdata van het CBS (eerder gepubliceerd in ROA-F-2020/5) 


\section{Figuur 7}

Complexiteitsindex van gemeenten

gericht op mensen in de bijstand

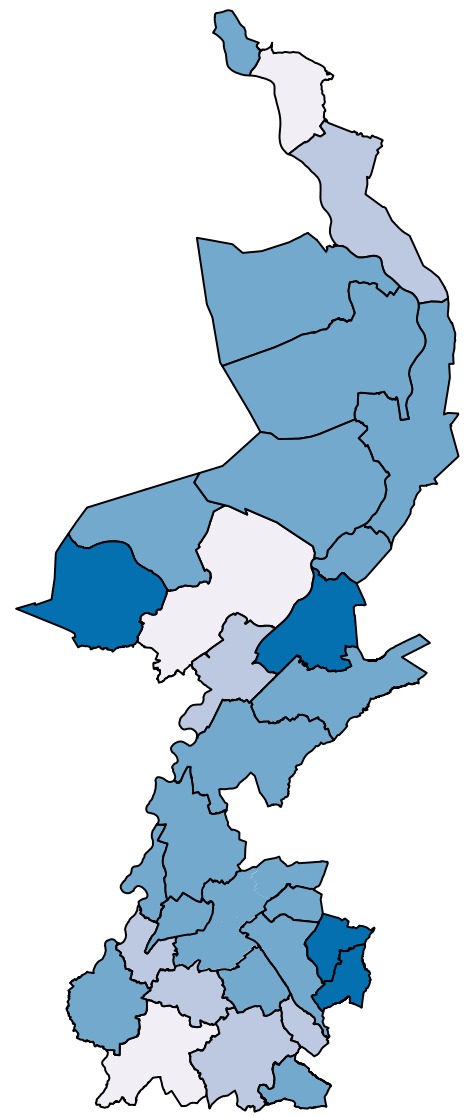

Geringe problematiek

Enkelvoudige problematiek

Meervoudige problematiek

Zeer complexe problematiek

Bron: ROA, berekeningen op basis van microdata van het CBS (eerder gepubliceerd in ROA-F-2020/5) 



\section{Verschillen in de profielen van bijstandsontvangers tussen de wijken in Heerlen}

We gaan nu in op verschillen tussen de wijken in de gemeente Heerlen. Tabel 2 brengt voor alle wijken in Heerlen in kaart hoe vaak een bepaalde problematiek voorkomt onder bijstandsontvangers. ${ }^{10}$ De mate waarin een bepaalde problematiek voorkomt onder de bijstandsontvangers in een bepaalde wijk wordt daarbij afgezet tegen de mate waarin deze problematiek voorkomt onder alle bijstandsontvangers in Heerlen. Tabel 2 laat goed zien dat er tussen de wijken verschillen zijn in de mate waarin bepaalde belemmerende factoren onder bijstandsontvangers voorkomen. Een aantal belangrijke bevindingen:

- Gezondheidsproblemen komen het meest voor onder bijstandsontvangers in de wijken Mariarade en De Koumen. In deze twee wijken komen gezondheidsproblemen voor bij meer dan $63 \%$ van de bijstandsontvangers.

- Het aandeel bijstandsontvangers met financiële problemen is het hoogst in de wijken Maria Gwanden en Terschuren en Welten-Benzenrade. Meer dan 83\% van de bijstandsontvangers in deze wijken heeft te maken met financiële problemen.

- Financiële problemen zijn de meest voorkomende problemen onder de bijstandsontvangers in Heerlen.

- Het aandeel bijstandsontvangers met een niet-westerse migratieachtergrond is het hoogst in de wijken Zeswegen-Nieuw Husken, Schandelen-Grasbroek, Meezenbroek-Schaesbergerveld en Eikenderveld. In deze wijken heeft meer dan $27 \%$ van de bijstandsontvangers een niet-westerse migratieachtergrond.

- De éénouderproblematiek is in Heerlen het grootst onder bijstandsontvangers die wonen in de wijken Nieuw Lotbroek, Rennemig-Beersdal, MeezenbroekSchaesbergerveld en Heerlerbaan-Schil. In deze wijken maakt meer dan 19\% van de bijstandsontvangers deel uit van een éénoudergezin.

- Het is opvallend dat er niet één wijk is waar alle aspecten van het profiel relatief gezien zeer veel voorkomen. Alleen in de wijk Meezenbroek-Schaesbergerveld komen onder de bijstandsontvangers twee aspecten zeer vaak voor: éénouderproblematiek en een niet-westerse migratieachtergrond.

- Tien van de 14 wijken waarvoor de index berekend kan worden worden gekenmerkt door een complexe problematiek.

Dit wordt ook duidelijk in gesprekken met zowel respondenten als consulenten. Veel mensen met een bijstandsuitkering hebben te maken met complexe problematiek al ontstaan tijdens hun jeugd. Het hebben van

10 In de appendix is een aanvullende tabel (Tabel A2) opgenomen met de ranking van wijken binnen de gemeente Heerlen met betrekking tot de verschillende aspecten die deel uitmaken van de profielschets. 
eerdere negatieve ervaringen met hulpverlening leidt tot wantrouwen tegenover de consulenten en daarmee tot mentale stress, welke de kans op een baan weer verkleint. Het moeten wachten op een uitkering leidt tot schulden.

Ook is het zonder startkwalificatie lastig om aan het werk te komen "werkgevers hebben liever werknemers met diploma" $\left(\mathrm{H}_{1}\right)$, wat de kans op een vaste baan verkleint en de kans op financiële problemen vergroot.

Natuurlijk heeft niet iedereen met een uitkering een complexe problematiek "Kijk er zitten ook mensen in de bijstand, die hebben ook bijvoorbeeld hbo-niveau, maar die krijgen door psychische klachten het allemaal even niet op een rijtje" (C4).

Bron: Schrijver, Bruinsma-Muller \& Stoffers (2020)

De aanvullende informatie uit Tabel $A 2$, waarin de ranking van de wijken is weergegeven voor de verschillende aspecten van de profielschets, geeft daarnaast nog de volgende inzichten:

- Bijstandsontvangers in een bepaald wijk ervaren vaak een hele andere problematiek dan bijstandsontvangers in andere wijken. Terwijl in de wijk Mariade gezondheidsproblemen relatief veel voorkomen onder bijstandsontvangers, is dit in de wijk Welten-Benzenrade veel minder het geval.

- Wijken hebben vaak met betrekking tot één of twee aspecten een (zeer) hoge positie, terwijl dat voor andere aspecten helemaal niet het geval is. In de wijk Hoensbroek-De Dem zijn er onder mensen met een bijstandsuitkering relatief veel problemen op het gebied van gezondheid en financiën, terwijl er relatief weinig éénoudergezinnen zijn en in vergelijking met andere wijken weinig bijstandsontvanges een niet-westerse migratieachtergrond hebben.

- In de wijken Molenberg en Heerlerheide-Passart, waar het percentage inwoners met een bijstandsuitkering het hoogst is, blijken bijstandsontvangers met name met gezondheidsproblemen te kampen te hebben. In de wijk Schandelen-Grasbroek, de wijk op de derde plek als het gaat om het aandeel inwoners met een bijstandsuitkering, komen daarentegen financiële problemen en een niet-westerse migratieachtergrond relatief veel voor. 


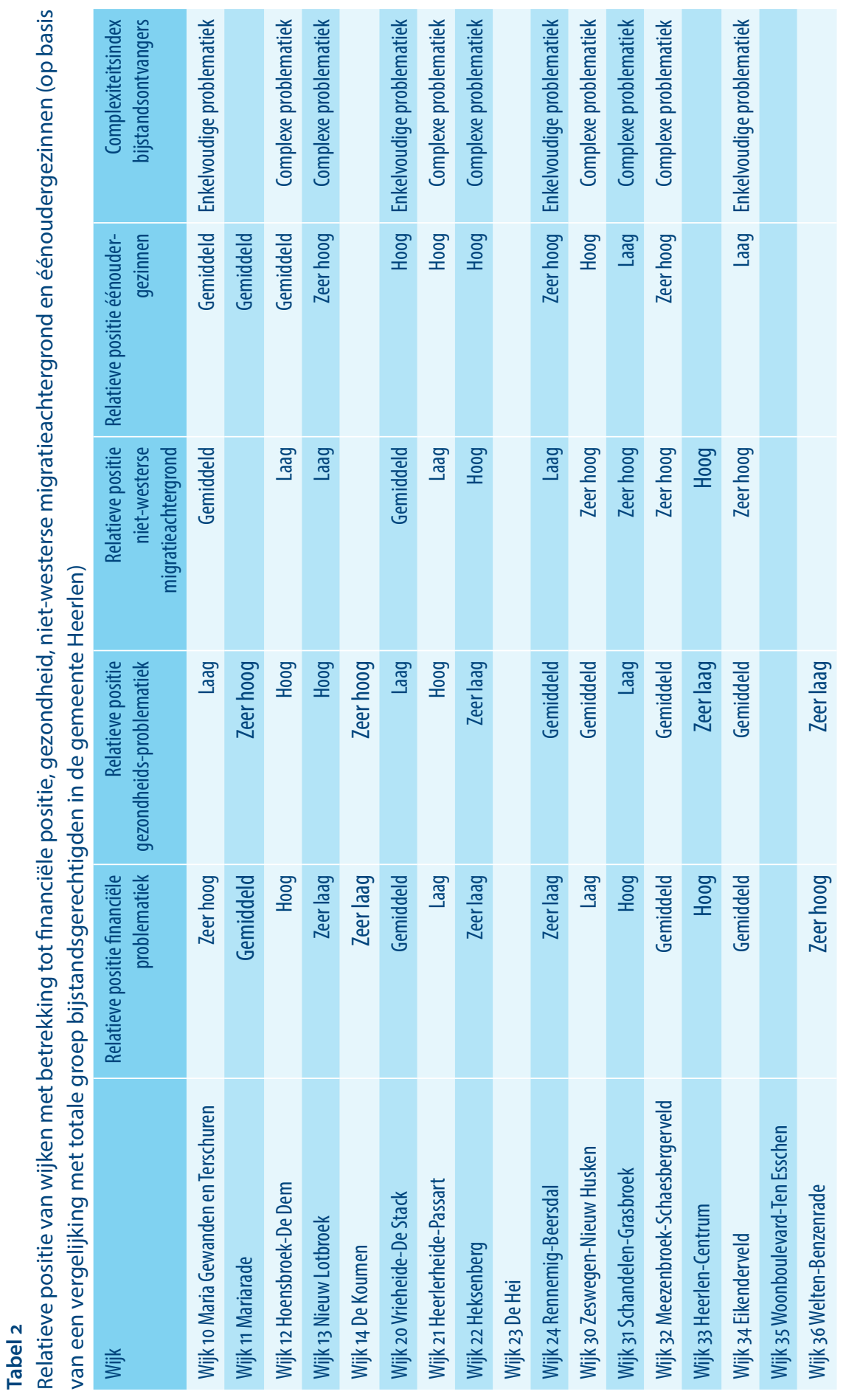




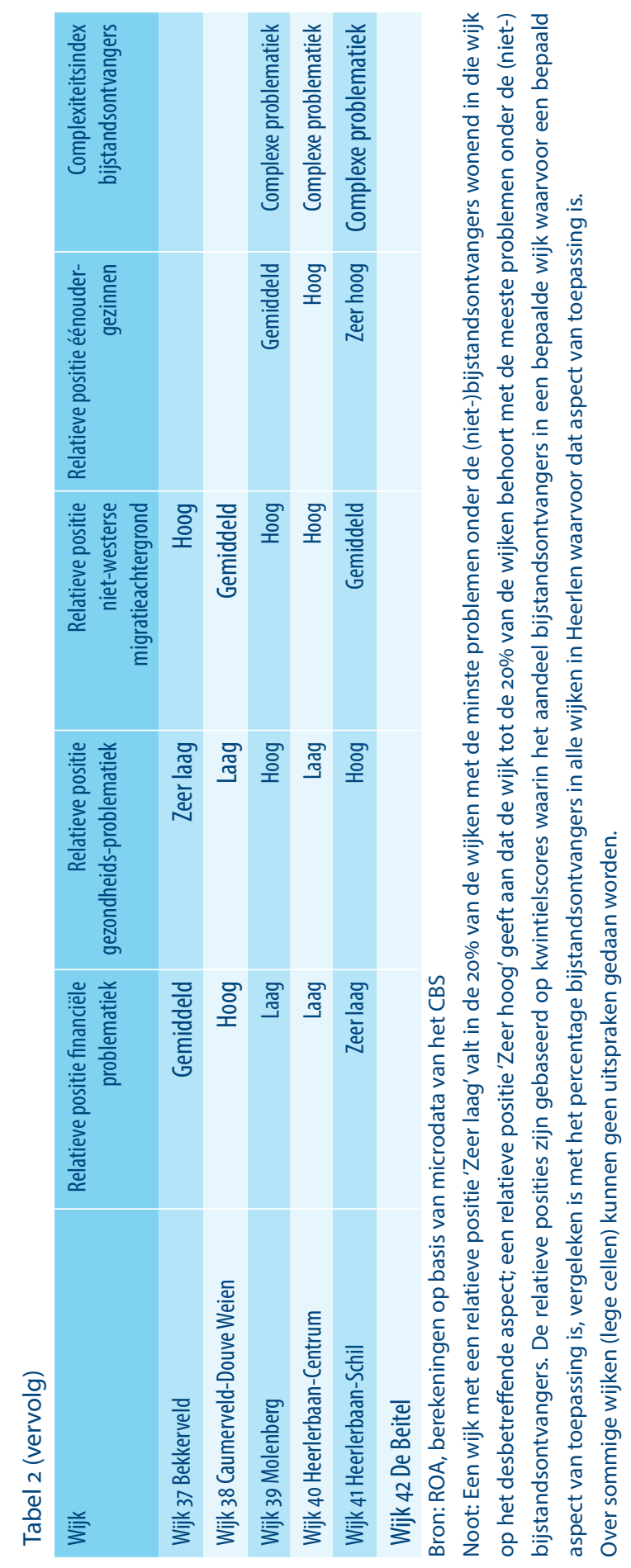


De kwintielgrenzen zijn als volgt:

\begin{tabular}{|l|r|r|r|r|}
\hline & $\begin{array}{r}\text { Gezondheids- } \\
\text { problematiek }\end{array}$ & $\begin{array}{r}\text { Financiële } \\
\text { problematiek }\end{array}$ & $\begin{array}{r}\text { Niet-westerse } \\
\text { migratieachtergrond }\end{array}$ & $\begin{array}{r}\text { Deel uitmaken } \\
\text { van een } \\
\text { éénoudergezin }\end{array}$ \\
\hline Eerste kwintiel & Minder dan $55 \%$ & Minder dan $71 \%$ & Minder dan $8 \%$ & Minder dan 2\% \\
\hline Tweede kwintiel & $55,1 \%-58,0 \%$ & $71,1 \%-75,0 \%$ & $8,1 \%-13,0 \%$ & $2,1 \%-14,0 \%$ \\
\hline Derde kwintiel & $58,1 \%-59,0 \%$ & $75,1 \%-79,0 \%$ & $13,1 \%-20,0 \%$ & $14,1 \%-16,0 \%$ \\
\hline Vierde kwintiel & $59,1 \%-63,0 \%$ & $79,1 \%-83,0 \%$ & $20,1 \%-27,0 \%$ & $16,1 \%-19,0 \%$ \\
\hline Vijfde kwintiel & Meer dan 63\% & Meer dan $83 \%$ & Meer dan 27\% & Meer dan $19,0 \%$ \\
\hline
\end{tabular}

Een gezondheidsprobleem wordt gedefinieerd o.b.v. het gebruik van medicatie voor een chronische ziekte en/of een status als gedeeltelijk arbeidsongeschikt zoals vastgesteld door het UWV. Een financieel probleem wordt gedefinieerd o.b.v. een huishoudinkomen onder de armoedegrens en/of schulden van minimaal $€ 10.000$,- en/of deelname aan een schuldsaneringstraject.

De complexiteitsindicator is gebaseerd op het aantal aspecten waar een wijk een (zeer) hoge relatieve positie heeft. Geringe problematiek = wijk scoort op geen enkel aspect (zeer) hoog; enkelvoudige problematiek = wijk scoort op één aspect (zeer) hoog; complexe problematiek = wijk scoort op twee dimensies (zeer) hoog; zeer complexe problematiek = wijk scoort op drie of vier dimensies (zeer) hoog. Enkele cellen zijn leeg gelaten i.v.m. onthullingsrisico als gevolg van een laag aantal observaties in deze wijken. 



\section{Profielschets van bijstandsontvangers en niet- bijstandsontvangers op wijkniveau in Heerlen}

In Hoofdstuk 4 hebben we laten zien in welke wijken bijstandsontvangers een relatief zwak profiel hebben. Echter, zonder verdere informatie is niet te zeggen of dit specifiek geldt voor de bijstandsontvangers, of dat alle inwoners in de desbetreffende wijken een relatief zwak profiel hebben. Daarom vergelijken we in dit hoofdstuk het profiel van de bijstandsontvangers in de verschillende wijken met het profiel van de andere inwoners in de wijk." De Figuren 8-11 laten op wijkniveau de relatieve positie zien van respectievelijk alle inwoners, de bijstandsontvangers en de niet-bijstandsontvangers. Hoe donkerder de blauwtint, hoe groter de relatieve problemen voor de desbetreffende groep inwoners.

In Figuur 8 is de relatieve positie van wijken op het gebied van financiële problematiek onder alle inwoners (panel a), de bijstandsontvangers (panel b) en de niet-bijstandsontvangers (panel c) weergegeven. In de wijken De Beitel, Molenberg, SchandelenGrasbroek en Heerlen-centrum is de financiële problematiek van alle inwoners als geheel zeer hoog. Dit wil zeggen dat in deze wijken meer dan 32\% van de inwoners een huishoudinkomen heeft onder de armoedegrens en/of schulden van minimaal $€ 10.000$,en/of deelneemt aan een schuldsaneringstraject. In de wijken Mariarade, Heksenberg, Rennemig-Beersdal en Heerlerbaan-Schil is de financiële problematiek, vergeleken met andere wijken in Heerlen, daarentegen zeer laag. Panel (b) laat zien dat in alle wijken van Heerlen waarvoor informatie beschikbaar is, meer dan $32 \%$ van de bijstandsontvangers te maken heeft met financiële problemen. Onder de niet-bijstandsontvangers geldt dat alleen voor de wijken Heerlen-Centrum en De Beitel.

11 Het betreft hier inwoners die behoren tot de potentiële beroepsbevolking en niet schoolgaand zijn of een (vervroegd) pensioen ontvangen. 


\section{Figuur 8}

Relatieve positie van wijken voor wat betreft de financiële problematiek

(a) alle inwoners

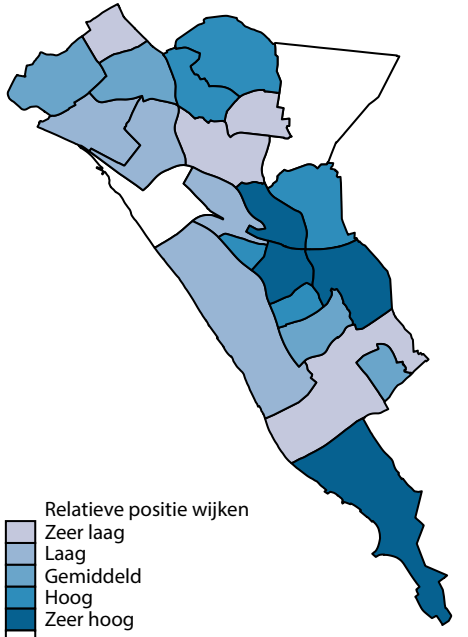

Geen data beschikbaar i.v.m. potentieel onthullingsrisico (b) bijstandsontvangers

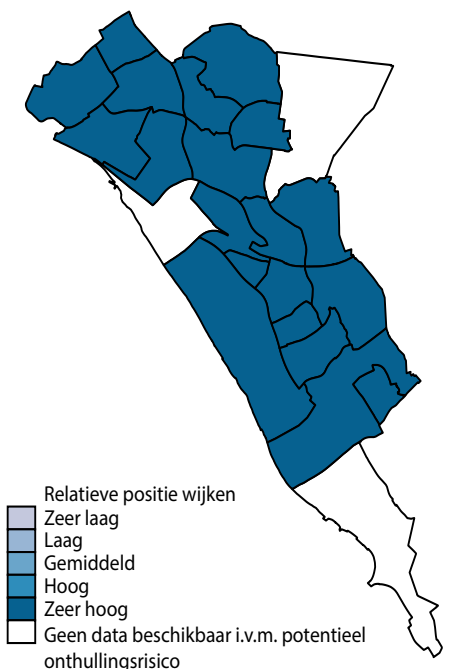

onthullingsrisico

(c) niet-bijstandsontvangers

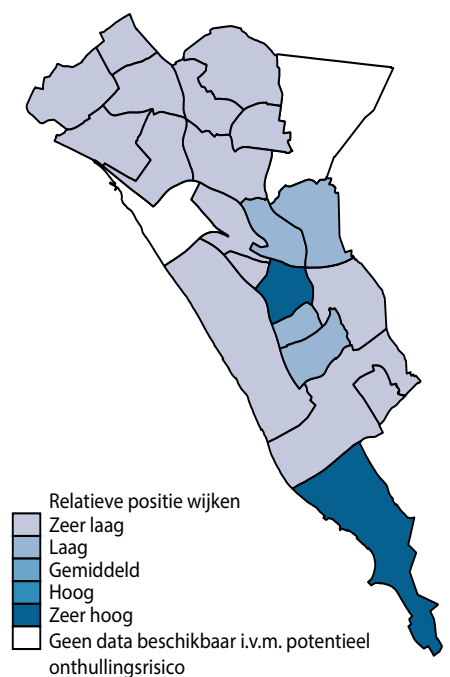

Bron: ROA, berekeningen op basis van microdata van het CBS

Noot: De relatieve positie van wijken is gebaseerd op de kwintielen, met de volgende kwintielgrenzen: zeer lage positie (minder dan $26,0 \%)$, lage positie $(26,1-29,0 \%)$, gemiddelde positie $(29,1-$ $30,0 \%)$, hoge positie $(30,1-32,0 \%)$, zeer hoge positie (meer dan 32\%). Over wijken met een witte arcering kan geen informatie verstrekt worden in verband met een potentieel onthullingsrisico. 
Figuur 9 geeft een overzicht van de relatieve positie van de Heerlense wijken voor wat betreft de gezondheidsproblematiek. Uit panel (a) blijkt dat relatief zeer veel inwoners in de wijken Vrieheide-De Stack, Heerlerheide-Passart, De Koumen en Woonboulevard-Ten Esschen gezondheidsproblemen ervaren. Het gaat daarbij in deze wijken om meer dan de helft van de inwoners. Gezondheidsproblemen komen ook relatief veel voor onder de inwoners van de wijken Maria-Gewanden en Terschuren, Hoensbroek-De Dem en Nieuw Lotbroek. Als we kijken naar alle inwoners, dan blijken de grootste gezondheidsproblemen zich te concentreren in de wijken in het noorden van Heerlen. Een uitzondering hierop vormt de wijk Mariarade, waar de gezondheidproblematiek op een relatief laag niveau ligt. Ook in de wijken De Beitel en Heerlerbaan-Centrum in Zuid Heerlen hebben relatief veel mensengezondheidsproblemen. Uit panel (b) blijkt dat gezondheidsproblemen onder bijstandsontvangers in de meeste wijken zeer veel voorkomen.

Veel respondenten met een uitkeringssituatie geven aan dat zij mentale problemen hebben. Deze worden niet veroorzaakt door de uitkeringssituatie, maar wel versterkt. Zo ervaren alle respondenten zowel veel stress rondom de aanvraag: "Het was voor mij destijds een heel stressvolle situatie" $\left(\mathrm{H}_{3}\right)$ als rondom de gesprekken met consulenten "Want als ik moet bellen, dan heb ik een stukje angst... of ik ben dan al zodanig over mijn grens heen dat ik gewoon bang ben dat ik ga flippen zeg maar" $\left(\mathrm{H}_{7}\right)$.

Bron: Schrijver, Bruinsma-Muller \& Stoffers (2020)

Uitzonderingen zijn de wijken Welten-Benzenrade, Bekkerveld en Heerlen-Centrum. Het percentage niet-bijstandsontvangers dat gezondheidsproblemen ervaart is relatief gezien zeer hoog in de wijken Vrieheide-Passart en De Beitel. 


\section{Figuur 9}

Relatieve positie van wijken voor wat betreft de gezondheidsproblematiek

(a) alle inwoners

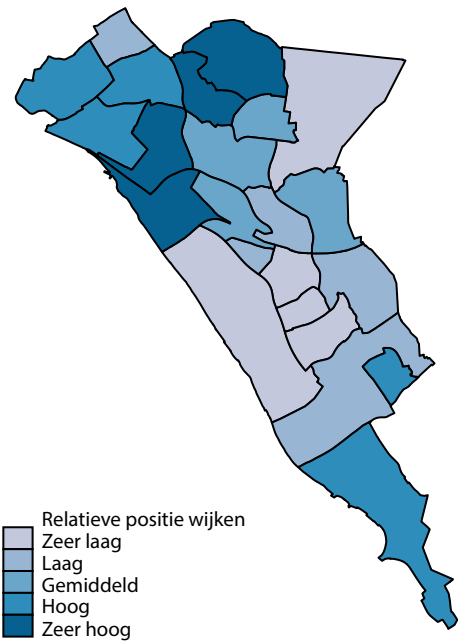

(b) bijstandsontvangers

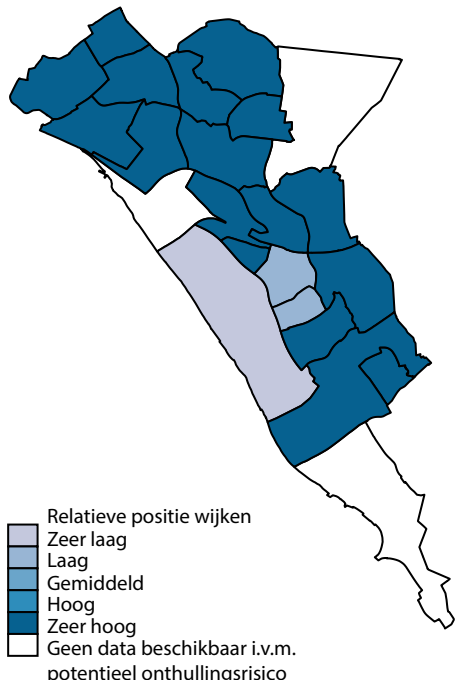

(c) niet-bijstandsontvangers

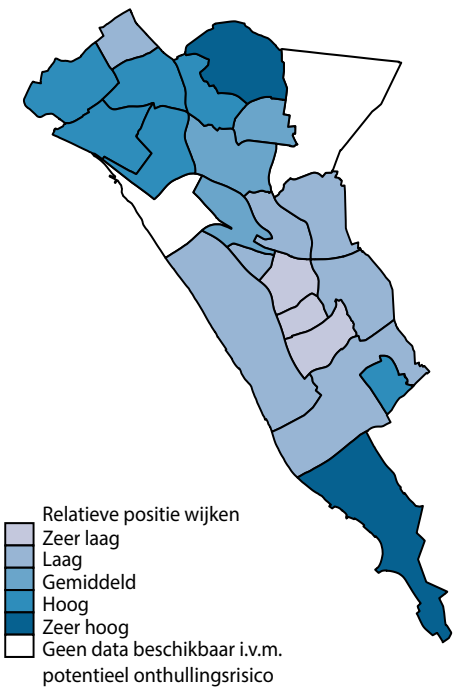

Bron: ROA, berekeningen op basis van microdata van het CBS

Noot: De relatieve positie van wijken is gebaseerd op de kwintielen, met de volgende kwintielgrenzen: zeer lage positie (minder dan $41,0 \%)$, lage positie $(41,1-47,0 \%)$, gemiddelde positie $(47,1-$ $49,0 \%)$, hoge positie $(49,1-50,0 \%)$, zeer hoge positie (meer dan 50\%). Over wijken met een witte arcering kan geen informatie verstrekt worden in verband met een potentieel onthullingsrisico. 


\section{Figuur 10}

Relatieve positie van wijken voor wat betreft de niet-Westerse migratieachtergrond

(a) alle inwoners

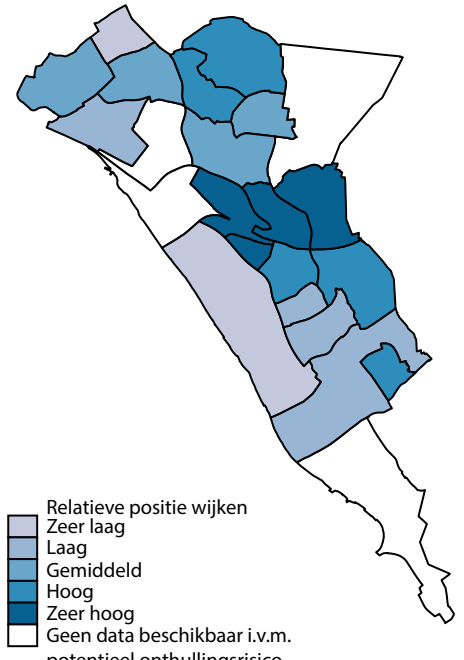

potentieel onthullingsrisico (b) bijstandsontvangers

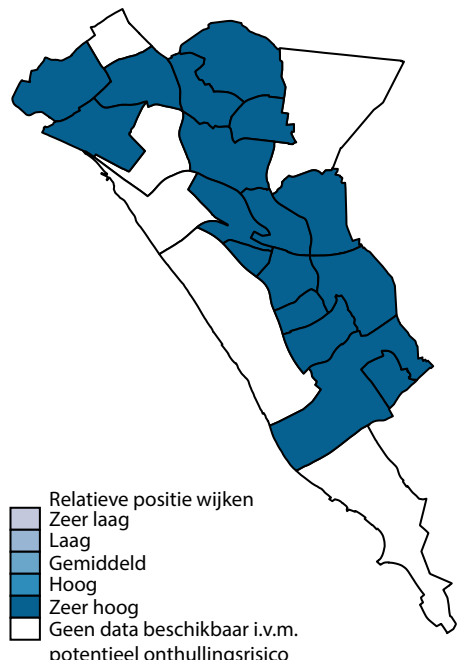

(c) niet-bijstandsontvangers

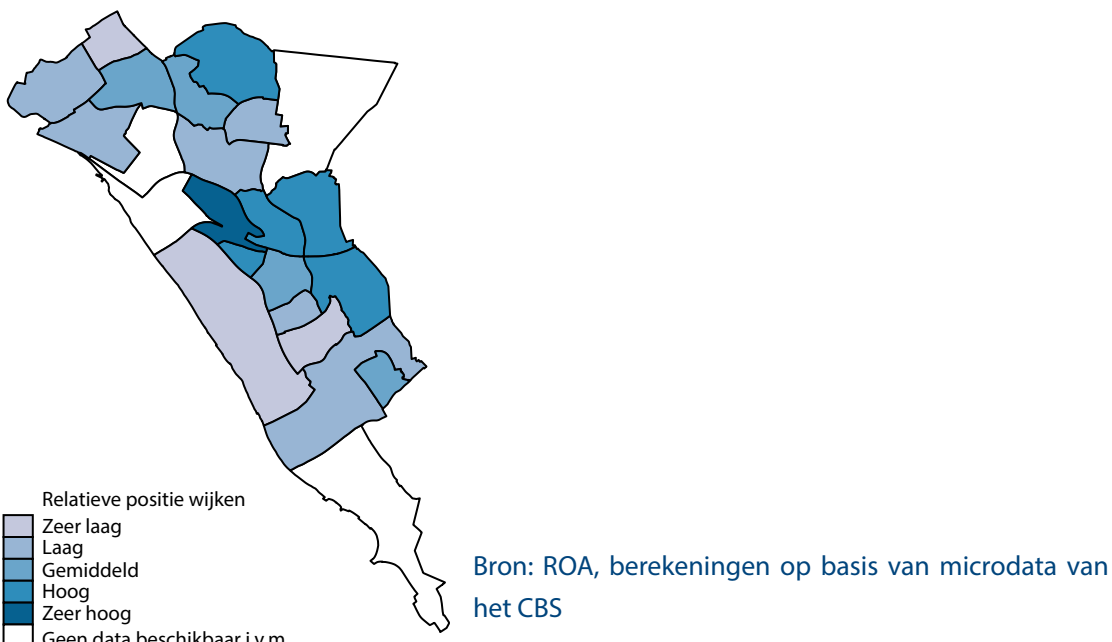

potentieel onthullingsrisico

Noot: De relatieve positie van wijken is gebaseerd op de kwintielen, met de volgende kwintielgrenzen: zeer lage positie (minder dan 2,0\%), lage positie (2,1-5,0\%), gemiddelde positie $(5,1-6,0 \%)$, hoge positie (6,1-9,0\%), zeer hoge positie (meer dan 9\%). Over wijken met een witte arcering kan geen informatie verstrekt worden in verband met een potentieel onthullingsrisico. 
In Figuur 10 is de relatieve positie van de wijken in Heerlen voor wat betreft het aandeel mensen met een niet-westerse migratieachtergrond weergegeven. Er is een duidelijk cluster van wijken waar dit aandeel zeer hoog is vergeleken met andere wijken. Het gaat om de wijken Meezenbroek-Schaesbergerveld, Schandelen-Grasbroek, ZesweegnNieuw Husken en Eikenderveld. In deze wijken heeft meer dan $9 \%$ van de inwoners een niet-westerse migratieachtergrond. Onder bijstandsontvangers heeft in alle wijken waarvoor informatie beschikbaar is meer dan $9 \%$ een niet-westerse migratieachtergrond. Onder de niet-bijstandsontvangers is dit alleen in de wijk Zeswegen-Nieuw Husken het geval.

Figuur 11 laat de relatieve positie van de wijken zien met betrekking tot het aandeel mensen dat deel uitmaakt van een éénoudergezin. De vier wijken waar relatief gezien zeer veel éénoudergezinnen wonen zijn Heerlerheide-Passart, MeezenbroekSchaesbergerveld, Molenberg en Heerlerbaan-Centrum. In deze wijken wonen meer dan $6 \%$ van de potentiële beroepsbevolking in een éénoudergezin. In de aangrenzende wijk Heerlen Centrum ligt dit percentage onder de 3\%. In elke wijk waarvoor informatie beschikbaar is, maakt meer dan $6 \%$ van de bijstandsontvangers deel uit van een éénoudergezin. 


\section{Figuur 11}

Relatieve positie van wijken voor wat betreft éénoudergezinnen

(a) alle inwoners

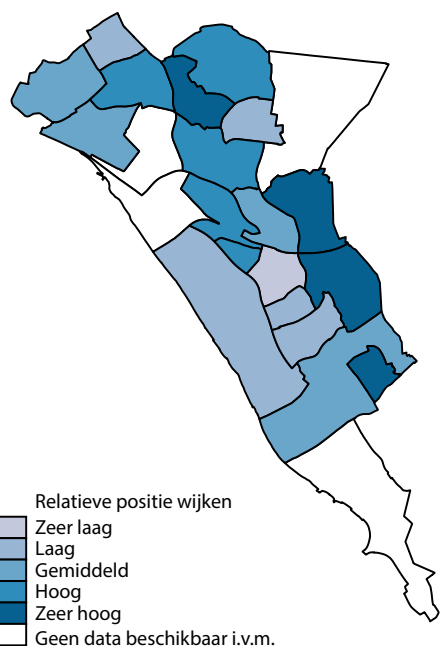

potentieel onthullingsrisico

(c) niet-bijstandsontvangers

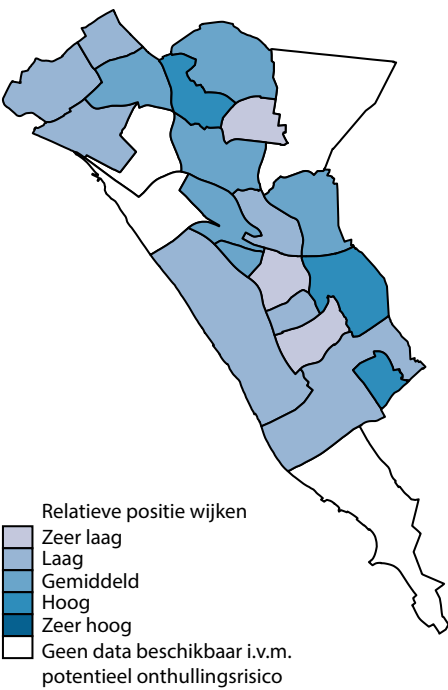

(b) bijstandsontvangers

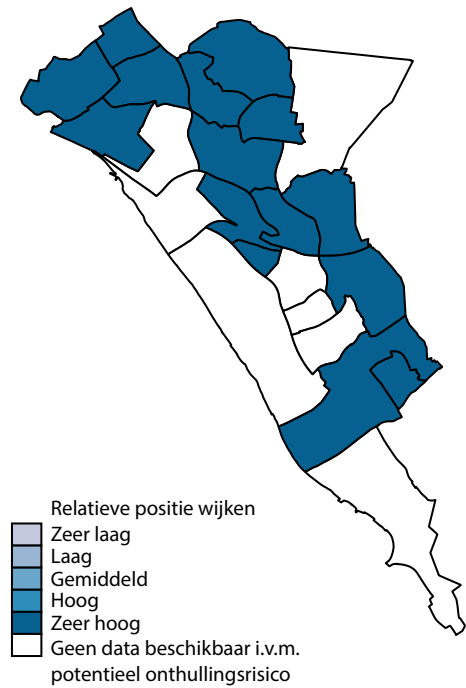

Bron: ROA, berekeningen op basis van microdata van het CBS

Noot: De relatieve positie van wijken is gebaseerd op de kwintielen, met de volgende kwintielgrenzen: zeer lage positie (minder dan 3,0\%), lage positie (3,1-4,0\%), gemiddelde positie (4,1-5,0\%), hoge positie $(5,1-6,0 \%)$, zeer hoge positie (meer dan $6 \%)$. Over wijken met een witte arcering kan geen informatie verstrekt worden in verband met een potentieel onthullingsrisico. 
Er is ook gekeken in hoeverre er in de verschillende wijken sprake is van een combinatie van factoren, waardoor het profiel van de inwoners van de wijk zwakker is. Daarbij maken we gebruik van een index die de complexiteit van de problematiek op wijkniveau weergeeft. Deze index is vergelijkbaar aan de index op gemeenteniveau, maar neemt het opleidingsniveau niet mee. ${ }^{12}$ In Figuur 12 wordt de complexiteitsindex op wijkniveau gepresenteerd.

12 Op het niveau van de wijken bleek het niet haalbaar om het opleidingsniveau van inwoners mee te nemen. Zie voetnoot 4 


\section{Figuur 12}

(a) alle inwoners

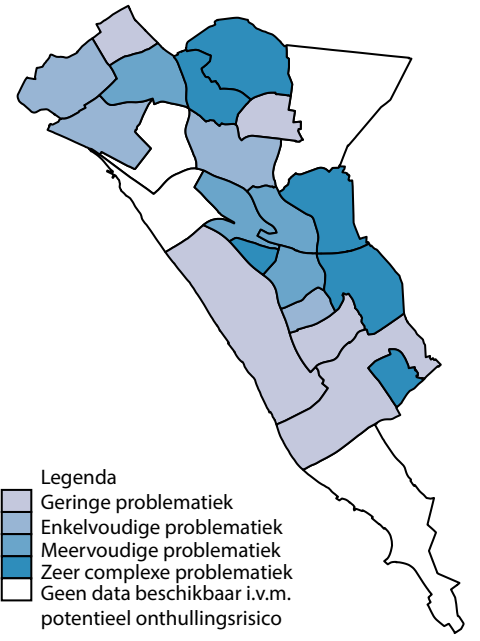

(b) bijstandsontvangers

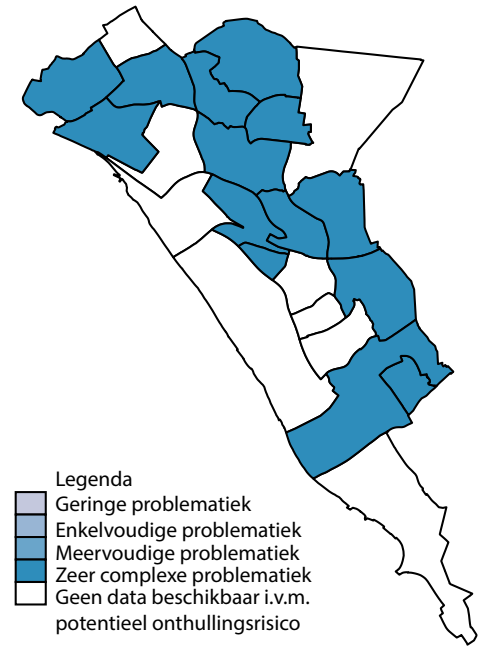

(c) niet-bijstandsontvangers

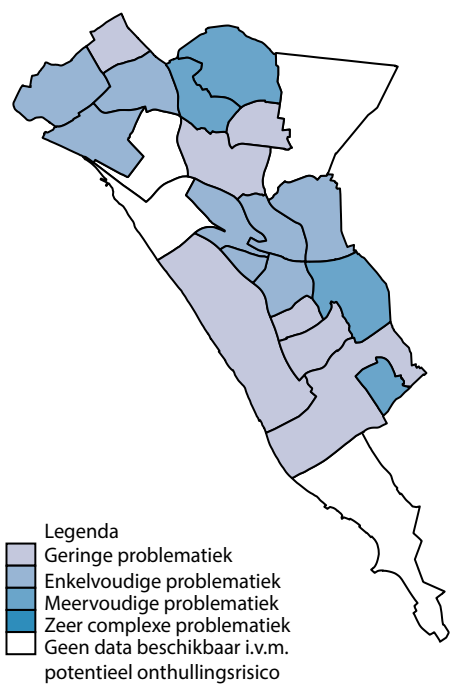

Bron: ROA, berekeningen op basis van microdata van het $C B S$

Noot: Geringe problematiek wil zeggen dat deze wijk op geen enkel aspect een (zeer) hoge relatieve positie inneemt. In een wijk met enkelvoudige problematiek komt onder de desbetreffende groep inwoners één aspect van de profielschets (zeer) veel voor. Van meervoudige problematiek wordt gesproken als de desbetreffende groep inwoners op twee aspecten (zeer) hoog scoort. Complexe problematiek wil zeggen dat drie of vier aspecten (zeer) veel voorkomen onder de desbetreffende groep inwoners. 
Uit Figuur 12 blijkt dat in alle wijken van Heerlen de problematiek onder bijstandsontvangers complex is. Alle onderliggende aspecten komen onder bijstandsontvangers (afgezet tegen alle inwoners) dus (zeer) veel voor.

Natuurlijk heeft niet iedereen met een uitkering een complexe problematiek "Kijk er zitten ook mensen in de bijstand, die hebben ook bijvoorbeeld hbo-niveau, maar die krijgen door psychische klachten het allemaal even niet op een rijtje" (C4).

Bron: Schrijver, Bruinsma-Muller \& Stoffers (2020)

Bij de niet-bijstandsontvangers is er daarentegen in veel wijken slechts sprake van een geringe of enkelvoudige problematiek. Alleen in de wijken Vrieheide-De Stack, Heerlerheide-Passart, Molenberg en Heerlerbaan-Centrum is de problematiek onder de niet-bijstandsontvangers meervoudig. ${ }^{13}$ Dit wil zeggen dat in deze wijken twee of drie aspecten van de profielschets (zeer) veel voorkomen. Als we kijken naar de gehele potentiële beroepsbevolking, dan zijn er zes wijken met een complexe problematiek (Vrieheide-De Stack, Heerlerweide-Passart, Meezenbroek-Schaesbergerveld, Eikenderveld, Molenberg, Heerlerbaan-Centrum) en vier wijken met een meervoudige problematiek (Hoensbroek-De Dem, Zeswegen-Nieuw Husken, Schandelen-Grasbroek, Heerlen-Centrum).

Respondenten noemen de volgende wijken als wijken waar meer mensen wonen met problemen: Heerlerheide (3x); Zeswegen (2x); Hoensbroek (2x); Mezenbroek (2x) en Rennemig (1x).

Bron: Schrijver, Bruinsma-Muller \& Stoffers (2020)

Op basis van de Figuren 8-12 kan het volgende geconcludeerd worden:

- Financiële problemen komen het meeste voor onder bijstandsontvangers. Het gaat hier om schulden boven de 10.000 Euro, een schuldsaneringstraject en/of een huishoudinkomen onder de armoedegrens.

- Éénoudergezinnen komen in alle wijken slechts in beperkte mate voor. Het percentage éénoudergezinnen is wel beduidend hoger onder mensen met dan zonder bijstandsuitkering.

- In alle wijken van Heerlenwaarvoor informatie beschikbaar is komen onder de bijstandsontvangers alle profielaspecten die het moeilijker kunnen maken om op de arbeidsmarkt te reintegrerenzeer veel voor. Zo zagen we dat in sommige wijken meer dan $63 \%$ van de bijstandsontvangers financiële problemen hebben (zie Tabel 2). Maar als alle inwoners meegenomen worden voor de berekening van de relatieve

13 Het is hierbij belangrijk om op te merken dat we over de wijken Woonboulevard-Ten Esschen (35), De Hei (23) en De Beitel (42) geen uitspraken kunnen doen over de complexiteit van de problematiek onder de nietbijstandsontvangers. 
posities, dan heeft een wijk al een zeer hoge positie als meer dan één op de drie inwoners financiële problemen heeft (zie Figuur 8). Bij de bijstandsontvangers is dat in alle wijken in Heerlen het geval.

- Mensen met een bijstandsuitkering in Heerlen hebben veel vaker te maken met een complexe problematiek dan mensen zonder een bijstandsuiterking. . 



\section{Ongelijkheid in problematiek onder bijstand- en niet-bijstandsontvangers}

Tabel 3 geeft een overzicht van de discrepantie tussen de mate waarin bepaalde aspecten voorkomen onder bijstands- en niet-bijstandsontvangers in de wijken van Heerlen. Uit deze tabel blijkt dat in de wijk Heerlerbaan-Schil de mate waarin financiële problemen, gezondheidsproblemen, niet-westerse migratieachtergrond en éénoudergezinnen voorkomen onder mensen met en zonder een bijstandsuitkering sterk verschilt. In de wijk Heerlerheide-Passart zijn de verschillen tussen deze twee groepen op alle aspecten juist relatief klein.

In de meeste wijken is er bij bepaalde aspecten juist een grote ongelijkheid tussen mensen met en zonder een bijstandsuitkering, terwijl dit niet het geval is op andere aspecten. Zo is de ongelijkheid in Welten-Benzenrade relatief groot als het gaat om financiële problemen, terwijl deze wijk de minste ongelijkheid vertoond tussen mensen met en zonder een bijstandsuitkering als het gaat om gezondheidsproblemen.

De tabel laat verder zien dat de wijken die het hoogste percentage bijstandsontvangers hebben met problemen op het gebied van financiën (Welten-Benzenrade), gezondheid (Mariarade) en éénoudergezin (Nieuw Lotbroek), ook de grootste verschillen hebben met niet-bijstandsontvangers. Dit geldt niet voor de wijk Schandelen-Grasbroek dat het hoogste percentage bijstandsontvangers heeft met een niet-westerse migratieachtergrond. Deze wijk heeft echter slechts plek 8 (van 17) als het gaat om de discrepantie op dit aspect tussen de bijstandsontvangers en niet-bijstandsontvangers. 


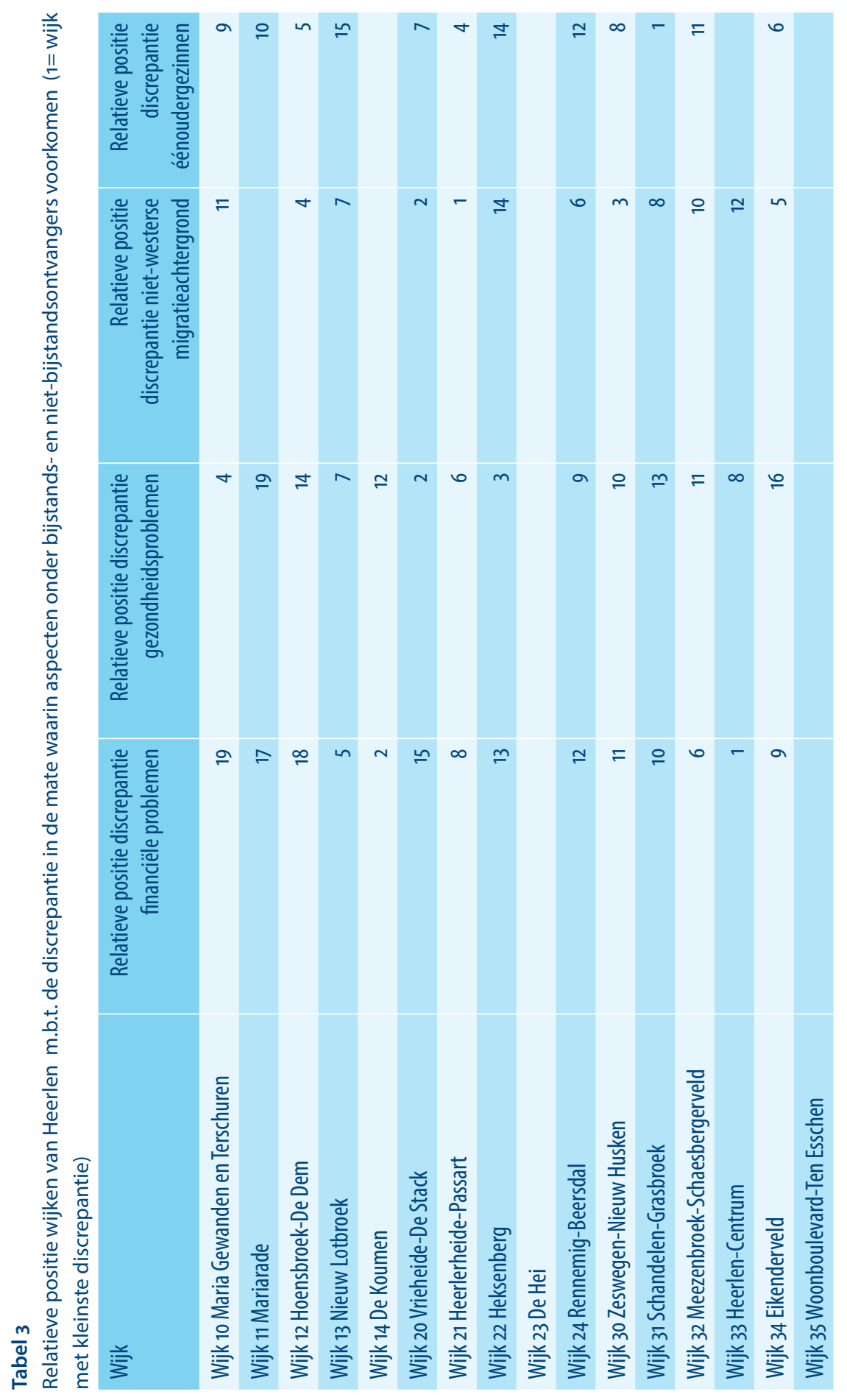




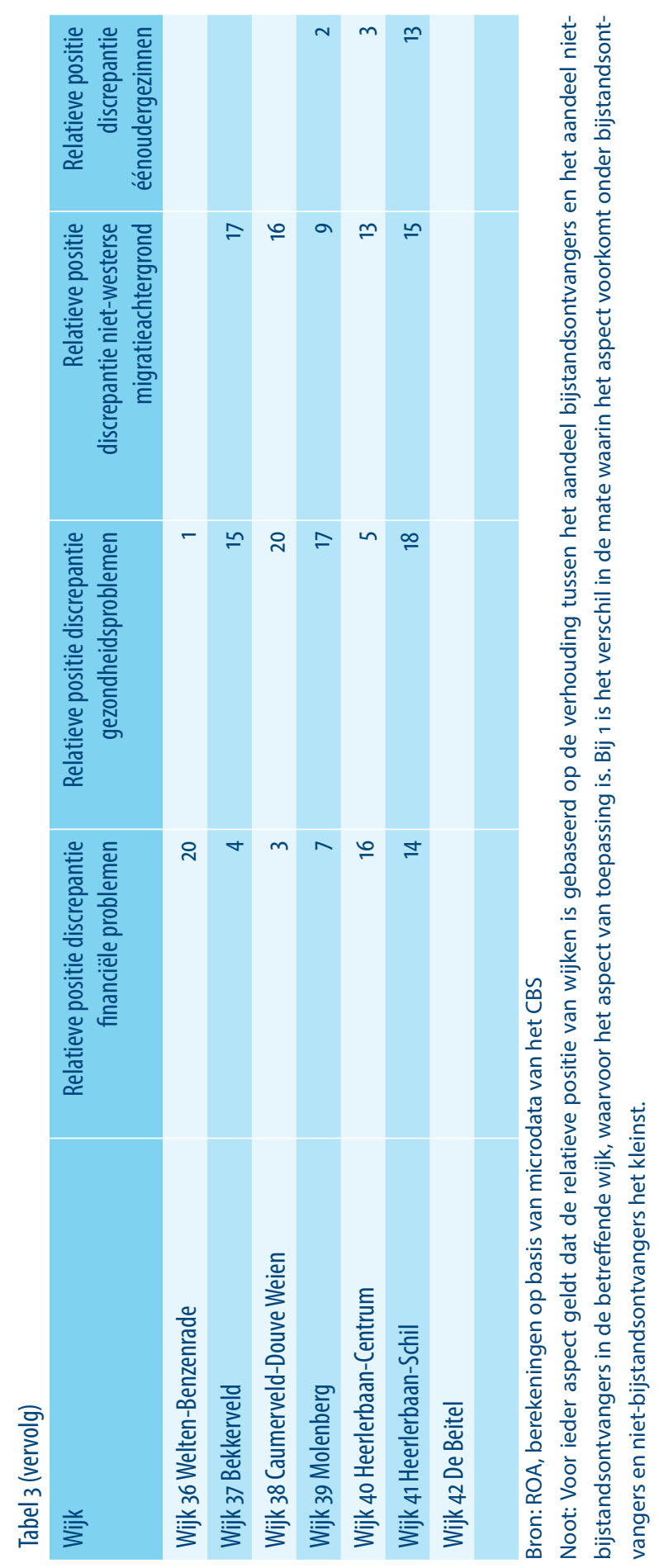





\section{Profiel van de bijstandsontvangers en de kans op reintegratie}

Nu we inzichtelijk hebben gemaakt wat het profiel is van de bijstandsontvangers in de wijken van Heerlenvoor wat betreft hun financiële problemen, gezondheidsproblemen, niet-Westerse migratieachtergrond en deel uitmaken van een éénoudergezin, willen we laten zien in hoeverre de verschillende aspecten van het profiel gerelateerd zijn aan de kans op reïntegratie. Om dit te kunnen bepalen zijn analyses uitgevoerd waarin op individueel niveau gekeken in in hoeverre de reïntegratiekansen van iemand met een bijstandsuitkering samenhangen met zijn of haar profielkenmerken. ${ }^{14}$

De analyses zijn uitgevoerd onder alle mensen woonachtig in Nederland, die in januari 2016 een bijstandsuitkering ontvingen en daarnaast niet werkzaam waren. Voor deze mensen is bepaald of zij in die maand financiële en/of gezondheidsproblemen hadden, laag opgeleid waren, een niet-westerse migratieachtergrond hadden en/of deel uitmaakten van een éénoudergezin. ${ }^{15}$

Vervolgens is gekeken naar de uitkeringsafhankelijkheid en de werkstatus van deze mensen anderhalf tot twee jaar later (dus in de periode juli - december 2017). Op basis daarvan zijn de bijstandsontvangers uit januari 2016 in vijf groepen verdeeld:

1. Niet werkzaam in december 2017.

2. Werkzaam in december 2017 , maar niet duurzaam en met behoud van uitkering in de laatste zes maanden van 2017.

3. Duurzaam aan het werk in december 2017, maar met behoud van uitkering in de laatste zes maanden van 2017.

4. Werkzaam zonder behoud van uitkering in december 2017 , maar niet duurzaam in de laatste zes maanden van 2017.

5. Duurzaam en zonder behoud van uitkering aan het werk in de laatste zes maanden van 2017.

Het merendeel van de mensen die in januari 2016 bijstand ontvingen zit in groep 1. Zij werkten in december 2017 niet (85\%). 3\% werkte in december 2017 (maar niet onafgebroken in de periode juli-december 2017) met behoud van uitkering (groep 2); nog eens $3 \%$ werkte in de gehele periode juli-december 2017 met behoud van uitkering (groep 3); $1 \%$ werkte in december 2017 zonder uitkering, maar was niet onafgebroken aan het werk

14 Om hiervan een zo betrouwbaar mogelijk beeld te kunnen geven zijn deze analyses gebaseerd op alle bijstandsontvangers in Nederland.

15 Dit is dus anders dan in de voorgaande paragrafen, waar we gerapporteerd hebben over de situatie in december 2017. 
in de periode juli-december 2017 (groep 4) en 6\% was duurzaam en volledig gereïntegreerd in de periode juli-december 2017 (groep 5).

Consulenten zien draaideurbijstandsgerechtigden: mensen die uitstromen naar werk en na een tijdje weer terugvallen in de bijstand: "uiteindelijk is deze klant uitgestroomd naar werk, fulltime. Is nu wel weer terug helaas, dus dan zie je wel zo'n cirkeltje ontstaan, waardoor zijn drugsgebruik ook weer meer wordt en eh dat soort dingen" (C4). Duurzame uitstroom zien consulenten weinig "Er zitten ook echt heel veel jongeren bij die het ècht niet kunnen"(C4).

Bron: Schrijver, Bruinsma-Muller \& Stoffers (2020)

Daarna hebben we op basis van een aantal multinominale logitanalyses onderzocht of het profiel van mensen met een bijstandsuitkering gerelateerd is aan hun kans om (duurzaam en volledig) te reïntegreren. Eerst hebben we gekeken in hoeverre financiële problemen, gezondheidsproblemen, een niet-westerse migratieachtergrond en het deel uitmaken van een éénoudergezin samenhangen met de kans om in één van bovengenoemde vijf groepen te vallen. De resultaten van deze analyses zijn samengevat in Tabel 4. 
Tabel 4

Analyseresultaten van het profiel en reïntegratiekansen

\begin{tabular}{|c|c|c|c|c|c|c|}
\hline \multirow{6}{*}{ 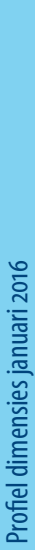 } & & $\begin{array}{r}\text { Groep 1: } \\
\text { Niet } \\
\text { werkzaam in } \\
\text { dec } 2017\end{array}$ & $\begin{array}{r}\text { Groep 2: } \\
\text { Werkzaam in } \\
\text { dec 2017, maar } \\
\text { met behoud } \\
\text { van uitkering }\end{array}$ & $\begin{array}{r}\text { Groep 3: } \\
\text { Werkzaam } \\
\text { gedurende } \\
\text { juli-dec 2017, } \\
\text { maar met } \\
\text { behoud van } \\
\text { uitkering }\end{array}$ & $\begin{array}{r}\text { Groep 4: } \\
\text { Volledig } \\
\text { gereïntegreerd } \\
\text { in dec } 2017\end{array}$ & $\begin{array}{r}\text { Groep 5: } \\
\text { Volledig } \\
\text { gereïntegreerd } \\
\text { gedurende } \\
\text { juli-dec } 2017\end{array}$ \\
\hline & Financiële problemen & $7 \%$ & 0 & 0 & 0 & $-6 \%$ \\
\hline & Gezondheidsproblemen & $4 \%$ & 0 & 0 & 0 & $-2 \%$ \\
\hline & $\begin{array}{l}\text { Niet-westerse } \\
\text { migratieachtergrond }\end{array}$ & $1 \%$ & 0 & 0 & 0 & $-2 \%$ \\
\hline & Éénoudergezinnen & $-2 \%$ & $1 \%$ & $1 \%$ & 0 & 0 \\
\hline & $\begin{array}{l}\text { Opleidingsniveau - } \\
\text { vmbo of lager }\end{array}$ & $7 \%$ & $-2 \%$ & $-2 \%$ & 0 & $-4 \%$ \\
\hline
\end{tabular}

Bron: $\mathrm{ROA}$, berekeningen en analyses op basis van microdata van het $\mathrm{CBS}$

Noot: De tabel is gebaseerd op alle inwoners van Nederland die in januari 2016 bijstand ontvingen. Vervolgens zijn alle inwoners in 5 groepen opgedeeld. (1) Niet werkzaam in december 2017, (2) Werkzaam met behoud van uitkering in december 2017, maar niet onafgebroken werkzaam in de periode juli-december 2017, (3) Werkzaam gedurende de periode juli-december 2017, maar gedurende minimaal één maand met behoud van een ww- of bijstandsuitkering, (4) Volledig gereïntegreerd in december 2017 maar niet onafgebroken aan het werk in de periode juli-december 2017, (5) Duurzaam en volledig gereïntegreerd. Een multinomiale logit analyse laat vervolgens zien in hoeverre de verschillende aspecten van het profiel, alsook de complexiteitsindex, gerelateerd zijn aan de kans om te behoren tot één van de vijf groepen.

De percentages geven marginale effecten weer. Marginale effecten van minder dan $1 \%$ worden op nul gezet.

Uit Tabel 4 blijkt onder andere dat bijstandsontvangers met financiële problemen $7 \%$ meer kans hebben om in december 2017 niet te werken dan voor inwoners zonder financiële problemen. Ook bijstandsontvangers met een opleidingsniveau van vmbo of lager hebben $7 \%$ meer kans om niet werkzaam te zijn vergeleken met bijstandsontvangers met een hoger opleidingsniveau.

Zowel respondenten met een uitkering als consulenten zien een relatie tussen het opleidingsniveau en de kans op werk. Consulenten zien een grote groep mensen met een uitkering die niet het vermogen hebben om zelf een betaalde baan te krijgen: "Een hele grote groep wat eigenlijk een heel laag IQ heeft, en ja daar kun je gewoon niet van verwachten dat ze dat zelf gaan vinden, een betaalde baan" (C3).

Het blijkt lastig om bij de opleiding passend werk te vinden: "voor sommige mensen is het moeilijk om iets te vinden wat echt op maat is voor die mensen" (H8). "Er zijn veel te weinig passende moeilijkheden" ( $\left.\mathrm{C}_{3}\right)$. De consulenten geven aan dat er slechts beperkt de mogelijkheid is om aan 
de slag te gaan in een ontwikkelbedrijf. Ook past het werkaanbod wat hier aangeboden wordt niet bij iedere bijstandsontvanger.

Bron: Schrijver, Bruinsma-Muller \& Stoffers (2020)

Gezondheidsproblemen (4\%) en een niet-Westerse migratieachtergrond (1\%) verlagen de kans op reïntegratie ook, maar de gevonden relaties zijn iets minder sterk.

Respondenten met een niet-westerse migratieachtergrond geven aan dat zij last hebben van vooroordelen "Je moet harder werken om je doel te bereiken als je een buitenlander bent" $\left(\mathrm{H}_{5}\right)$.

De meeste respondenten noemen vooral de taal als grootse probleem "Dan zegt de werkgever 'je Nederlands is te slecht' $\left(\mathrm{C}_{5}\right)$. Naast taal wordt ook de andere culturele achtergrond ervaren als barrière: "Sommige statushouders zijn gewoon om te werken als je geld nodig hebt" (C6).

Bron: Schrijver, Bruinsma-Muller \& Stoffers (2020)

Opvallend is dat bijstandsontvangers die deel uitmaken van een éénoudergezin een significant grotere kans hebben om werkzaam te zijn in december 2017.

Alleenstaand ouderschap wordt gezien als belastend: "zo moet dus bijvoorbeeld een alleenstaande moeder zowel de rol van vader als de rol van moeder spelen, waardoor aan een bepaalde baan komen een uitdaging wordt" $\left(\mathrm{H}_{1}\right)$. Zowel thuis als op het werk wordt veel van alleenstaande ouders gevraagd: "Nou, ik heb een hele tijd gewerkt en dan was ik alleen en dan moest ik mijn kinderen verzorgen en daardoor liep ik nog meer op mijn tandvlees" $\left(\mathrm{H}_{4}\right)$. Zeker bij jongere kinderen blijkt het lastig voor alleenstaande ouders om aan de slag te komen. Kinderopvang is duur, waardoor werken minder snel lonend is. Ook is het lastig om een plek te krijgen op de kinderopvang, sluiten de openingstijden onvoldoende aan bij de werktijden van beschikbare banen en is het aanvragen van kinderopvangtoeslag ingewikkeld.

Bron: Schrijver, Bruinsma-Muller \& Stoffers (2020)

De kolommen 2 en 3 laten zien dat alleenstaande bijstandsontvangers met minimaal één kind veelal onvolledig reïntegreren. Dit wil zeggen dat zij naast het werk dat ze verrichten in de tweede helft van 2017, ook nog ww of bijstand ontvangen. 


\section{Complexiteit van de problematiek van de bijstandsontvangers en de kans op reïntegratie}

Naast de losse profieldimensies hebben we ook gekeken naar de mate waarin de complexiteit van de problematiek gerelateerd is aan de kans op (volledige en duurzame) reïntegratie. Omdat uit bovenstaande analyses bleek dat het profiel voornamelijk gerelateerd is aan de kans om al dan niet te werken en om al dan niet duurzaam en volledig te reïntegreren, beperken we ons nu alleen tot twee verklarende analyses:

1. De kans om al dan niet werkzaam te zijn in december 2017

2. De kans om duurzaam en volledig gereïntegreerd te zijn, dat wil zeggen gedurende de maanden juli-december 2017 onafgebroken werkzaam geweest te zijn zonder behoud van een ww of bijstandsuitkering.

We bekijken allereerst in hoeverre deze kansen gerelateerd zijn aan een individuele indexscore. Deze score geeft het aantal aspecten van het profiel aan tot op ieder individu van toepassing is. Deze indexscore loopt daarmee op van nul tot vijf. De individuele indexscore geeft hiermee de complexiteit van de problematiek op individueel niveau weer.

In Tabel 5 zijn de resultaten opgenomen. We hebben twee soorten analyses gedraaid. In de eerste analyse is de individuele indexscore lineair opgenomen, in de tweede analyse laten we gedifferentieerde effecten toe tussen bijvoorbeeld het van toepassing zijn van geen en één aspect, en drie en vier aspecten van de profielschets. De individuele indexscore blijkt gerelateerd aan de kans op (volledige en duurzame) reïntegratie. Voor elk aspect dat op bijstandsontvangers van toepassing is, neemt de kans op reïntegratie met $5 \%$ af (kolom 1). Hiermee is het verschil in reïntegratiekansen tussen iemand zonder problemen en iemand met zeer complexe problemen (op alle vijf de gebieden) bijna een kwart.

De gezinssituatie is ook van invloed op de kansen die kinderen krijgen om actief te worden op de arbeidsmarkt. Door gebrek aan ondersteuning door en voorbeeld van twee ouders is is het voor de kinderen lastiger om een goede opleiding te volgen "Als alleenstaande ouder verlies je heel snel overzicht en word je [als kind] gewoon aan je lot overgelaten. En als een leraar daar niets van zegt en alleen maar strafwerk geeft, ja dat is niet de oplossing natuurlijk" $\left(\mathrm{H}_{2}\right)$. Ook hebben alleenstaande ouders financieel minder middelen, waardoor de kinderen opgroeien in armere wijken waar andere waarden en normen heersen: "zij vinden het ook heel normaal om met criminaliteit in aanraking te komen en met drugs" (C4). 
Indien ouder(s) niet werken en daarnaast in het gezin financiële problematiek en/of gezondheidsproblematiek speelt, dan heeft dat invloed op de opvoeding: "Als ik naar mijn verleden kijk, dan herken ik dat wel, maar $i k$ hoop dat ik mijn kinderen toch wel een betere opvoeding heb gegeven en ook wel minder problemen dan ik heb gehad" $\left(\mathrm{H}_{4}\right)$.

Bron: Schrijver, Bruinsma-Muller \& Stoffers (2020)

Het blijkt dat de kans om werkzaam te zijn in december 2017 vooral afhangt van het al dan niet van toepassing zijn van de aspecten van de profielschets in januari 2016 (kolom 2). Bijstandsontvangers waarvoor één aspect van toepassing is hebben een $13 \%$ lagere kans op werk in december 2017 dan bijstandsontvangers waarvoor geen enkel aspect van toepassing is. Als men te maken heeft met twee aspecten van de profielschets, neemt de kans met nog eens $5 \%$ verder af. De mate waarin een additioneel aspect effect heeft op de reïntegratiekansen beperkt zich daarna tussen de $4 \%$ en $2 \%$. Indien bijstandsontvangers te maken hebben met alle vijf de aspecten hebben zij een $28 \%$ lagere kans om werkzaam te zijn in december 2017.

\section{Tabel 5}

Relatie tussen de complexiteit van de problematiek en iemands reïntegratiekansen

\begin{tabular}{|c|c|c|c|c|}
\hline & \multicolumn{2}{|c|}{ Werkzaam in december 2017} & \multicolumn{2}{|c|}{ Duurzame en volledige reïntegratie } \\
\hline & (1) & (2) & (3) & (4) \\
\hline Individuele indexscore (lineair) & $-5 \%$ & & $-3 \%$ & \\
\hline \multicolumn{5}{|l|}{ Individuele indexscore (o is ref) } \\
\hline 1 & & $-13 \%$ & & $-11 \%$ \\
\hline 2 & & $-18 \%$ & & $-15 \%$ \\
\hline 3 & & $-22 \%$ & & $-17 \%$ \\
\hline 4 & & $-24 \%$ & & $-19 \%$ \\
\hline 5 & & $-28 \%$ & & $-20 \%$ \\
\hline
\end{tabular}

Bron: ROA, berekeningen en analyses op basis van microdata van het CBS

Noot: Tabel toont coëfficiënten van een OLS analyse, waarin gecontroleerd is voor geslacht en leeftijd. De individuele indexscore is de optelsom van het aantal aspecten dat voor die inwoners in januari 2016 van toepassing zijn. Hiermee heeft de score voor elke persoon een waarde 0, 1, 2, 3, 4 of 5 . Kolom (1) en (2) hebben als afhankelijke variabele of iemand werkzaam was in december 2017. Kolom (3) en (4) hebben als afhankelijke variabele of iemand onafgebroken werkzaam was in de periode juli-december 2017 zonder behoud van een ww- of bijstandsuitkering.

Kolom (3) en (4) laten de resultaten zien voor vergelijkbare analyses. Echter, nu wordt niet alleen gekeken naar het al dan niet hebben van werk in december 2017, maar wordt ook meegenomen of iemand duurzaam aan het werk is geweest (onafgebroken aan het werk tussen juli-december 2017) en volledig aan het werk is (zonder behoud van een ww of bijstandsuitkering). De coëfficiënten van model 4 zijn iets kleiner dan van model 2. Dit wil zeggen dat iemands (complexe) problematiek sterker samenhangt met de kans om überhaupt te gaan werken dan met de kans om duurzaam en volledig te reïntegreren. 
Naast persoonsgebonden aspecten zijn ook institutionele aspecten van invloed op de mogelijkheid om duurzaam te (re-)integreren.

Naast regulatieve instituties, de wet- en regelgeving, zijn ook normatieve instituties, de wijkcultuur, van invloed op de kans op duurzame (re-)integratie. In een wijk waar de werkloosheid hoog is en veel mensen een uitkering ontvangen, lijkt het ontvangen van een uitkering de norm te worden: "Die bijstandsuitkering is eigenlijk wel normaal" ( $\left.\mathrm{C}_{4}\right)$. Handelen tegen de heersende norm in, wordt als lastig ervaren: "Het is wel moeilijker als iedereen om je heen stoer doet en niet werkt" $\left(\mathrm{H}_{3}\right)$.

Bron: Schrijver, Bruinsma-Muller \& Stoffers (2020)

In een laatste stap hebben we gekeken in hoeverre veelvoorkomende combinaties van aspecten gerelateerd zijn aan iemands kans op reïntegratie. Hiertoe hebben we allereerst gekeken wat veelvoorkomende combinaties van aspecten zijn. ${ }^{16}$ Daaruit bleek het volgende:

- $4 \%$ van de bijstandsontvangers heeft slechts te maken met één aspect van de profielschets, tegenover $29 \%$ van alle inwoners. In ongeveer een derde van de gevallen (32\%) betreft het dan financiële problemen. ${ }^{17}$

- $23 \%$ van de bijstandsontvangers heeft te maken met twee aspecten van de profielschets, tegenover $16 \%$ van alle inwoners. In dit geval gaat het meestal (34\%) om een combinatie van financiële problemen en gezondheidsproblemen.

- $16 \%$ van de bijstandsontvangers heeft te maken van drie aspecten van de profielschets, tegenover $3 \%$ van alle inwoners. Het gaat hier het vaakst $(33 \%)$ om een combinatie van financiële problemen, gezondheidsproblemen en een laag opleidingsniveau.

- Op 13\% van de bijstandsontvangers zijn vier aspecten van toepassing, tegenover $2 \%$ van alle inwoners. Het betreft vrijwel altijd (70\%) een combinatie van financiële en gezondheidsproblemen, een laag opleidingsniveau en een niet-westerse migratieachtergrond.

- $2 \%$ van de bijstandsontvanger heeft te maken met alle vijf aspecten, tegenover (afgerond) o\% van alle inwoners.

Als er eenmaal financiële problemen zijn, is dit van invloed op de mentale gezondheid: "Sommigen die echt diep erin zitten, dan kan ik me wel voorstellen dat sommigen denken van ja, dat is ook wel een beetje afgelopen" (H8). Tegelijkertijd neemt de kans op hulp toe: "Op het moment dat ze geen geld hebben dan word je ook inderdaad door instanties gezien als iemand die zorg nodig heeft" $(\mathrm{H} 8)$.

16 We rapporteren de meest voorkomende combinaties onder alle inwoners (m.u.v. de situatie waarin één aspect van toepassing is). Zie voetnoot 17.

17 Als we naar alle inwoners kijken, dan komen gezondheidsproblemen het meest voor (49\%). Echter, onder bijstandsontvangers komen financiële problemen het meest voor wanneer er sprake is van enkelvoudige problematiek (59\%). 
Andersom worden mentale gezondheidsproblemen ook als oorzaak gezien van financiële problemen: "Zelf heb ik ook wel een deurwaarder aan de deur gehad. Ik had toen mentale problemen" $\left(\mathrm{H}_{3}\right)$.

Bron: Schrijver, Bruinsma-Muller \& Stoffers (2020)

\section{Tabel 6}

Analyseresultaten van veel voorkomende combinaties van aspecten en reïntegratiekansen

\begin{tabular}{|c|c|c|}
\hline & $\begin{array}{l}\text { Werkzaam in } \\
\text { december } 2017 \\
\text { (1) }\end{array}$ & $\begin{array}{l}\text { Duurzame en volledige } \\
\text { reïntegratie } \\
\text { (2) }\end{array}$ \\
\hline \multicolumn{3}{|c|}{$\begin{array}{l}\text { Veel voorkomende combinaties van aspecten } \\
\text { (geen enkel aspect van toepassing is referentie categorie) }\end{array}$} \\
\hline Financiële problemen & $-20 \%$ & $-17 \%$ \\
\hline en gezondheidsproblemen & $-20 \%$ & $-17 \%$ \\
\hline en laag opleidingsniveau & $-24 \%$ & $-18 \%$ \\
\hline en niet-westerse migratieachtergrond & $-25 \%$ & $-19 \%$ \\
\hline en éénoudergezin & $-28 \%$ & $-20 \%$ \\
\hline
\end{tabular}

Bron: ROA, berekeningen en analyses op basis van microdata van het CBS

Tabel toont coëfficiënten van een OLS analyse, waarin gecontroleerd is voor geslacht en leeftijd. In de analyses zijn alle inwoners in Nederland die in januari 2016 een bijstandsuitkering ontvingen meegenomen. De vijf verschillende veel voorkomende combinaties zijn stapsgewijs opgebouwd. Mensen waarvoor geen één aspect van toepassing is vormen de referentiegroep. Kolom (1) heeft als afhankelijke variabele of iemand werkzaam was in december 2017. Kolom (2) heeft als afhankelijke variabele of iemand onafgebroken werkzaam was in de periode juli-december 2017 zonder behoud van een ww- of bijstandsuitkering.

Vervolgens is gekeken in hoeverre deze veelvoorkomende combinaties gerelateerd zijn aan de kans op (duurzame en volledige) reïntegratie. Tabel 7 geeft een overzicht van de resultaten.

Het hebben van financiële problemen verkleint de kans op werk bijna twee jaar later met $20 \%$.

Financieel gaat iemand die uit een uitkering komt en gaat werken voor een minimumloon, er op korte termijn weinig op vooruit. Sterker nog, ze kunnen er financieel zelfs op achteruit gaan: "plus er is geen verschil tussen werkenden en iemand die in een uitkering zit" ( $\left.\mathrm{H}_{5}\right)$. Bijstandsontvangers met een laag opleidingsniveau, alleenstaande ouders in het bijzonder, gaan er financieel op achteruit als ze gaan werken. "Die moeten het echt hebben van een eigen intrinsieke motivatie" $\left(\mathrm{C}_{3}\right)$.

Bron: Schrijver, Bruinsma-Muller \& Stoffers (2020) 
Het is vervolgens niet van groot belang voor de reïntegratiekansen of iemand naast de financiële problemen ook nog gezondheidsproblemen heeft. Als er naast deze twee problemen ook sprake is van een laag opleidingsniveau, zien we wel een relatief grote afname in de kans op werk in december 2017. Ten opzichte van mensen waarvoor geen enkel aspect van toepassing is, ligt de kans op werk in december 2017 bijna een kwart lager onder bijstandsontvangers waarvoor deze drie aspecten gelden. Zoals Tabel 5 al laat zien, blijkt dat als bijstandsontvangers te maken hebben met alle vijf de aspecten, zij $28 \%$ minder kans hebben om werkzaam te zijn in december 2017 dan bijstandsontvangers waarvoor geen één aspect van toepassing is. Ook de kans op duurzame en volledige reïntegratie hangt samen met de veel voorkomende combinaties van aspecten (kolom 2). Echter, de kans op volledige en duurzame reïntegratie blijkt vooral af te hangen van het al dan niet hebben van financiële problemen. De additionele aspecten leiden elk tot een verdere afname van de kans op volledige en duurzame reïntegratie van slechts $1 \%$. 



\section{Conclusie}

Dit rapport is bedoeld als handvat voor de gemeente Heerlen bij het monitoren en aanscherpen van het reïntegratiebeleid voor de bijstandsontvangers in de gemeente. Het brengt in kaart in hoeverre bijstandsontvangers in de verschillende wijken van Heerlen te maken hebben met gezondheidsproblemen, financiële problemen, een nietwesterse migratieachtergrond en/of deel uitmaken van een éénoudergezin. Vervolgens is gekeken in hoeverre bijstandsontvangers met deze problemen en achtergrondkenmerken (en de daaruit voortvloeiende complexiteit van hun problematiek) een kleinere kans hebben om op de arbeidsmarkt te reïntegreren.

Dit rapport brengt een aantal belangrijke inzichten:

- Bijstandsontvangers hebben het meest te maken met financiële problemen. Daarbij kijken we naar drie indicatoren: een huishoudinkomen onder de armoedegrens, schulden van minimaal 10.000 Euro of een schuldsaneringstraject (Tabel 2). Ook gezondheidsproblemen komen relatief veel voor (Tabel 2).

- Tussen de wijken in Heerlen is er veel verschil in de problematiek waarmee bijstandsontvangers te kampen hebben. Ook is er veel verschil in hun achtergrondkenmerken (Tabel 2).

- Wanneer een wijk onder bijstandsontvangers relatief hoog scoort op één aspect, is het niet altijd zo dat zij ook relatief hoog scoren op de andere aspecten (Tabel 2).

- Voor vrijwel alle wijken in Heerlen geldt dat er onder bijstandsontvangers sprake is van een zeer complexe problematiek, terwijl dit veel minder vaak het geval is bij niet-bijstandsontvangers (Figuur 12).

- Binnen wijken is er vaak een groot verschil in de mate waarin inwoners die bijstand ontvangen financiële of gezondheidsproblemen ondervinden en degenen die geen bijstand ontvangen. Datzelfde geldt voor hun achtergrondkenmerken. Ook zien we regelmatig dat dit verschil betrekking heeft op één of twee aspecten, maar juist niet op de andere aspecten (Tabel 3).

- Alle onderzochte profieldimensies hangen samen met een lagere kans om duurzaam en volledig op de arbeidsmarkt te reïntegreren. Dit geldt het sterkst bij financiële en gezondheidsproblemen (Tabel 4). 
- Met uitzondering van het deelmaken van een éénoudergezin, hangen alle aspecten ook samen met een hogere kans om bijna twee jaar later niet te werken. Mensen die deel uitmaken van een éénoudergezin hebben juist een grotere kans om werkzaam te zijn, maar dat geldt alleen voor werk met behoud van een (ww- of bijstands)uitkering (Tabel 4).

- Los van de specifieke aspecten, blijkt ook de complexiteit van de problematiek belangrijk voor iemands reïntegratiekansen. Bijstandsontvangers waarvoor alle vijf aspecten van toepassing zijn hebben bijna twee jaar later ruim twee keer zo weinig kans op werk dan bijstandsontvangers waarop slechts één aspect van toepassing is: $28 \%$ versus $12 \%$ minder kans in vergelijking tot bijstandsontvangers zonder problemen (Tabel 5).

- De complexiteit van de problematiek speelt ook een rol in de kans om duurzaam en volledig te reïntegreren. De kans om duurzaam en volledig te reïntegreren neemt ongeveer twee keer zo sterk af als op bijstandsontvangers vijf aspecten (in plaats van één aspect) van toepassing zijn: $20 \%$ versus $11 \%$ (Tabel 5).

- Als op iemand één aspect van toepassing is, is dit ongeveer even sterk gerelateerd aan de kans om twee jaar later te werken dan aan de kans om dan ook duurzaam en volledig gereïntegreerd te (Tabel 5).

- Hoe complexer de problematiek, hoe groter het verschil tussen de kans om 23 maanden later te werken en de kans om dan ook duurzaam en volledig gereïntegreerd te zijn. Dat betekent dat bij complexe problematiek vooral de kans om überhaupt te gaan werken lager is. Dit suggereert dat als voor deze groep de horde om werk te vinden eenmaal genomen is, een complexe problematiek minder nadelig is voor het behoud van werk zonder aanvullende uitkering dan voor het reïntegreren an sich (Tabel 6).

- Bijstandsontvangers met financiële problemen hebben een veel kleinere kans op (duurzame en volledige) reïntegratie. Of naast deze financiële problemen ook nog gezondheidsproblemen aan de orde zijn, doet er voor de (duurzame en volledige) reïntegratiekansen nauwelijks toe. Pas als men daarnaast ook laagopgeleid is, keldert de kans op reïntegratie weer duidelijk. Dit laatste geldt echter niet voor de kans op een duurzame en volledige reïntegratie (Tabel 6).

- Financiële problemen zijn de belangrijkste oorzaak van reïntegratieproblemen:Veel bijstandsontvangers kampen met financiële problemen, die sterk gerelateerd zijn met iemands reïntegratiekansen.

Deze inzichten gecombineerd met de inzichten uit het kwalitatieve onderzoek dat Zuyd Hogeschool heeft verricht binnen het 4Limburg programma, resulteren in een aantal beleidsuitdagingen: 
- Bijstandsontvangers waarop slechts één aspect van toepassing is, hebben $13 \%$ minder kans om te reïntegreren dan bijstandsontvangers waarop geen enkel aspect van toepassing is. Bovendien is voor deze groep de kans om bijna twee jaar later duurzaam en volledig gereïntegreerd te zijn ongeveer even klein. Daarom is het van groot belang om in te zetten op het verminderen van de financiële- en gezondheidsproblemen van bijstandsontvangers.

- Volgens de respondenten uit het kwalitatief onderzoek is daarnaast ook iemands persoonlijke houding van invloed.

"Mensen willen gewoon niet werken" $\left.\mathrm{H}_{5}\right)$ is een veelgehoorde gemeenschappelijke overtuiging als het gaat over bijstandsontvangers. Bijstandsontvangers hebben deze overtuiging zelf ook, als het gaat om anderen dan zijzelf.

Bron: Schrijver, Bruinsma-Muller \& Stoffers (2020)

- Zowel consulenten als respondenten met een uitkering geven daarbij echter aan dat het niet willen werken vaak veroorzaakt wordt door persoonlijke omstandigheden (Schrijver e.a. 2020). In een poging de houding van mensen te veranderen, zal dus toch vooral gekeken moeten worden naar mogelijkheden om het profiel van mensen te versterken. Dit is ook van belang omdat zowel het profiel als ook de uitkeringsafhankelijkheid vaak van generatie op generatie overgedragen wordt (Schrijver e.a. 2020).

Hoewel bijstandsontvangers het beste wensen voor hun kinderen, " $k$ doe mijn best voor mijn kinderen en dan zie ik wel waar ze eindigen" $\left(\mathrm{H}_{5}\right)$, leidt dit niet altijd tot het gewenste effect als (beide) ouders niet werkten of werken: "Omdat die kinderen niet anders gewend zijn dan dat voorbeeld in feite" $(\mathrm{H} 7)$. "Ze weten vaak ook niet beter, want moeder en vader werken ook inderdaad niet" (C).

Bron: Schrijver, Bruinsma-Muller \& Stoffers (2020)

- Tussen wijken zijn er grote verschillen in de mate waarin bijstandsontvangers te maken hebben met financiële - en gezondheidsproblemen. Dit pleit voor een wijkgerichte aanpak van deze problematiek.

- Omdat in sommige wijken financiële problemen relatief veel voorkomen en gezondheidsproblemen relatief minder vaak of andersom, zou per wijk gekeken moeten waar in het beleid de focus op zou moeten liggen.

- Deze rapportage laat zien in welke wijken relatief veel bijstandsontvangers financiële problemen hebben. In deze wijken zou het beleid op wijkniveau en individueel niveau elkaar moeten aanvullen. Daarbij kan men denken aan infor- 
matiesessies over financieel management voor mensen in de bijstand in combinatie met het faciliteren van schuldhulpmaatjes. In wijken waarin er veel verschil is in de financiële positie tussen bijstands- en niet-bijstandsontvangers, kunnen schuldhulpmaatjes geworven worden onder niet-bijstandsontvangers uit de buurt. Buurtpunten zouden hier een rol kunnen spelen.

- In wijken met relatief veel bijstandsontvangers met financiële problemen zouden ook informatiesessies gehouden kunnen worden op scholen. Zo worden kinderen en jongeren al vroeg bekend met goede manieren om met geld om te gaan.

- In wijken met relatief veel gezondheidsproblemen onder bijstandsontvangers, zou meer aandacht uit moeten gaan naar een gezonde leefstijl. Zo zou beweging gestimuleerd kunnen worden (door buitenfitness mogelijkheden) en meer aandacht moeten komen voor gezonde voeding. Initiatieven op het gebied van zowel beweging als voeding kunnen ook plaatsvinden rondom scholen zodat ook kinderen (van bijstandsontvangers) geholpen worden een gezondere leefstijl te ontwikkelen. In 2019 had $17 \%$ van alle scholen in Nederland een vignet Gezonde School van het programma Gezonde school. ${ }^{18}$

- Het ontbreekt veel bijstandsontvangers ook aan vertrouwen in instanties en hulpverleners. Eenmaal wonend in een wijk waar de werkloosheid hoog is en veel mensen een uitkering ontvangen, lijkt het ontvangen van een uitkering de norm te worden.

"Die bijstandsuitkering is eigenlijk wel normaal" (C4); "Het is wel moeilijker als iedereen om je heen stoer doet en niet werkt" $\left(\mathrm{H}_{3}\right)$.

Bron: Schrijver, Bruinsma-Muller \& Stoffers (2020)

- Een wijkgerichte aanpak met veel maatwerk zou het vertrouwen en de norm in de wijk kunnen opkrikken.

Het opbouwen van wederzijds vertrouwen zien alle respondenten als belangrijk. Volgens de consulenten lukt dat alleen als je elkaar regelmatig ziet gedurende een langere periode "Het is belangrijk dat je vertrouwen houdt van de klant en ook dat ze weten, je kunt altijd op mij bouwen" (C4). De bijstandsontvangers vinden het belangrijk dat gekeken wordt naar hun mogelijkheden en niet naar hun onmogelijkheden: "Ik denk dat de gemeente zich ook moet focussen op de capaciteiten van de persoon zelf" $(\mathrm{H} 7)$.

Bron: Schrijver, Bruinsma-Muller \& Stoffers (2020)

- Veel bijstandsontvangers ervaren problemen bij al het (digitale) papierwerk dat gepaard gaat met het aanvragen en behouden van bijstand. 
"Als je ziet wat voor een waslijsten ze daar [schuldhulpverlening] al voor een intake mee moeten nemen, daar zou ik zelf nog moeite mee hebben" ( $\left.\mathrm{C}_{4}\right)$

Bron: Schrijver, Bruinsma-Muller \& Stoffers (2020)

- Dit kan schuldenproblematiek en een geringe bereidheid tot reïntegreren versterken. Het is in deze context belangrijk in te zetten op het vergroten van de (digitale) geletterdheid van bijstandsontvangers. ${ }^{19}$

- Onze anlyses laten zien dat alleenstaande ouders relatief vaak uitstromen naar werk, maar dat zij wel afhankelijk blijven van een uitkering. Alleenstaande ouders geven aan dat regels rondom de kinderopvang en toeslagen het hen lastig maken om aan de slag te gaan.

"Om te zorgen dat je dat allemaal geregeld hebt en net op het moment voordat je moet gaan werken, zoals wij dat ook allemaal moeten doen, dat is toch best ingewikkeld allemaal. Dus die drempel is vrij hoog" (C $\left.C_{5}\right)$.

Bron: Schrijver, Bruinsma-Muller \& Stoffers (2020)

- Bovendien is kinderopvang duur, waardoor werken minder snel lonend is. Ook geven ze aan dat het lastig is om een plek te krijgen op de kinderopvang, sluiten de openingstijden onvoldoende aan bij de werktijden en is het aanvragen van kinderopvangtoeslag moeilijk. Het is belangrijk om te kijken hoe alleenstaande ouders ondersteund kunnen worden in hun reïntegratie omdat werk mogelijk kan voorkomen dat zij financiële problemen krijgen. Ook al zijn het kleine banen waarnaast een uitkering nog noodzakelijk is. Het opplussen van werk is makkelijker dan een reïntegratietraject op latere leeftijd als de kinderen de deur uit zijn.

- Ons onderzoek laat zien dat als bijstandsontvangers met complexe problematiek de horde om werk te vinden eenmaal genomen hebben, hun complexe problematiek minder nadelig is voor het behoud van werk zonder aanvullende uitkering. Dit suggereert dat ook bijstandsontvangers met complexe problematiek aangemoedigd en gefaciliteerd moeten worden om aan het werk te gaan.

- Werkgevers zouden zich hierbij flexibel moeten opstellen en, net als de gemeenten, maatwerk moeten bieden. Functieherontwerp kan hierbij een waardevolle rol vervullen..$^{20}$ Er heerst nu nog de opvatting dat werkgevers eisen stellen waar mensen met een laag opleidingsniveau niet aan kunnen voldoen, zoals diploma-eisen, de eis fulltime te werken, eigen vervoer, etc. (Schrijver e.a. 2020). Werkgevers dienen ook gestimuleerd te worden. Door financiële prikkels en een beroep op hun maatschappelijke verantwoordelijkheid zullen werkgevers eerder bereid zijn een bijstandsont-

19 Zie: Huijts, T., Bijlsma, I. \& Van der Velden, R. (2020). Wetenschappelijke verantwoording doelgroepenanalyse laaggeletterden. https://geletterdheidinzicht.nl.

20 Zie: Mulders, H., Van Ruitenbeek, G. \& Zijlstra, F. (2020). Methode Inclusief Herontwerp van Werk vernieuwd: IHW2.o. Tijdschrift voor Bedrijfs- en Verzekeringsgeneeskunde, vol. 28(8), pp. 46-49; Van Ruitenbeek, G., Mulders, H. \& Zijlstra, F. (2019). Inclusief organiseren opent nieuwe perspectieven. Sociaal bestek, maart 2019, pp.46-48. 
vanger aan te nemen. Werkgevers kunnen ondersteund worden door de gemeente door bijvoorbeeld vanuit de gemeente begeleiding van de (her)intreder op de werkplek te bieden.

"Voor sommige mensen is het moeilijk om iets te vinden wat echt op maat is voor die mensen" ( $\mathrm{H} 8)$, "Er zijn veel te weinig passende mogelijkheden" $\left(\mathrm{C}_{3}\right)$.

Bron: Schrijver, Bruinsma-Muller \& Stoffers (2020)

- Uitkeringsafhankelijken noemen ook negatieve beelden die heersen bij werkgevers over mensen met een uitkering (en over mensen met een migratieachtergrond ${ }^{21}$ ) die belemmerend werken bij de kans op reïntegratie.

"Bij de bijstand wordt iedereen eigenlijk als rotte appel gezien" (H8).

Bron: Schrijver, Bruinsma-Muller \& Stoffers (2020)

- Het gebrek aan banen bij werkgevers en de afwijzingen die kandidaten ontvangen op sollicitaties werkt demotiverend en verkleint de kans op werken in de toekomst (Schrijver e.a. 2020).

"Je hebt er heel veel gesprekken mee en je kneedt ze en uiteindelijk zijn ze dan zo ver dat ze kunnen gaan en dan is er geen plek, ja dan raakt iemand heel snel weer gedemotiveerd" (C5).

Bron: Schrijver, Bruinsma-Muller \& Stoffers (2020)

Uit discussies met verschillende gemeenten over onze onderzoeksuitkomsten komen bovendien de volgende punten naar boven:

- Onze bevindingen bevestigen het beeld dat sommige gemeenten schetsen: het gemeentelijk beleid moet niet in kolommen gevoerd, maar er moet rekening gehouden moet worden met de multiproblematiek waarmee mensen te maken hebben.

- Het is van belang om zowel de omvang als de complexiteit van de problematiek van uitkeringsafhankelijken te monitoren. Op deze manier kunnen gemeenten (en ook regio's) zien waar zij ten opzichte van elkaar staan en hoe zij zich ontwikkelen en kunnen binnen een gemeente vergelijkingen worden gemaakt tussen wijken.

21 Zie voorbeelden in de tekstbox op pagina 38. 


\section{Bijlage A: Additionele tabellen}

Tabel A1

Ranking wijken op basis van het hoogste aandeel inwoners met een bijstandsuitkering

Wijk 39 Molenberg

Wijk 21 Heerlerheide-Passart

Wijk 31 Schandelen-Grasbroek

Wijk 34 Eikenderveld

Wijk 32 Meezenbroek-Schaesbergerveld

Wijk 40 Heerlerbaan-Centrum

Wijk 20 Vrieheide-De Stack

Wijk 14 De Koumen

Wijk 12 Hoensbroek-De Dem

Wijk 10 Maria Gewanden en Terschuren

Wijk 30 Zeswegen-Nieuw Husken

Wijk 13 Nieuw Lotbroek

Wijk 33 Heerlen-Centrum

Wijk 24 Rennemig-Beersdal

Wijk 37 Bekkerveld

Wijk 22 Heksenberg

Wijk 11 Mariarade

Wijk 38 Caumerveld-Douve Weien

Wijk 36 Welten-Benzenrade

Wijk 41 Heerlerbaan-Schil

Bron: ROA, berekeningen op basis van microdata van het CBS

Noot: Een drietal wijken zijn missing (i.v.m. te weinig bijstandsontvangers) 


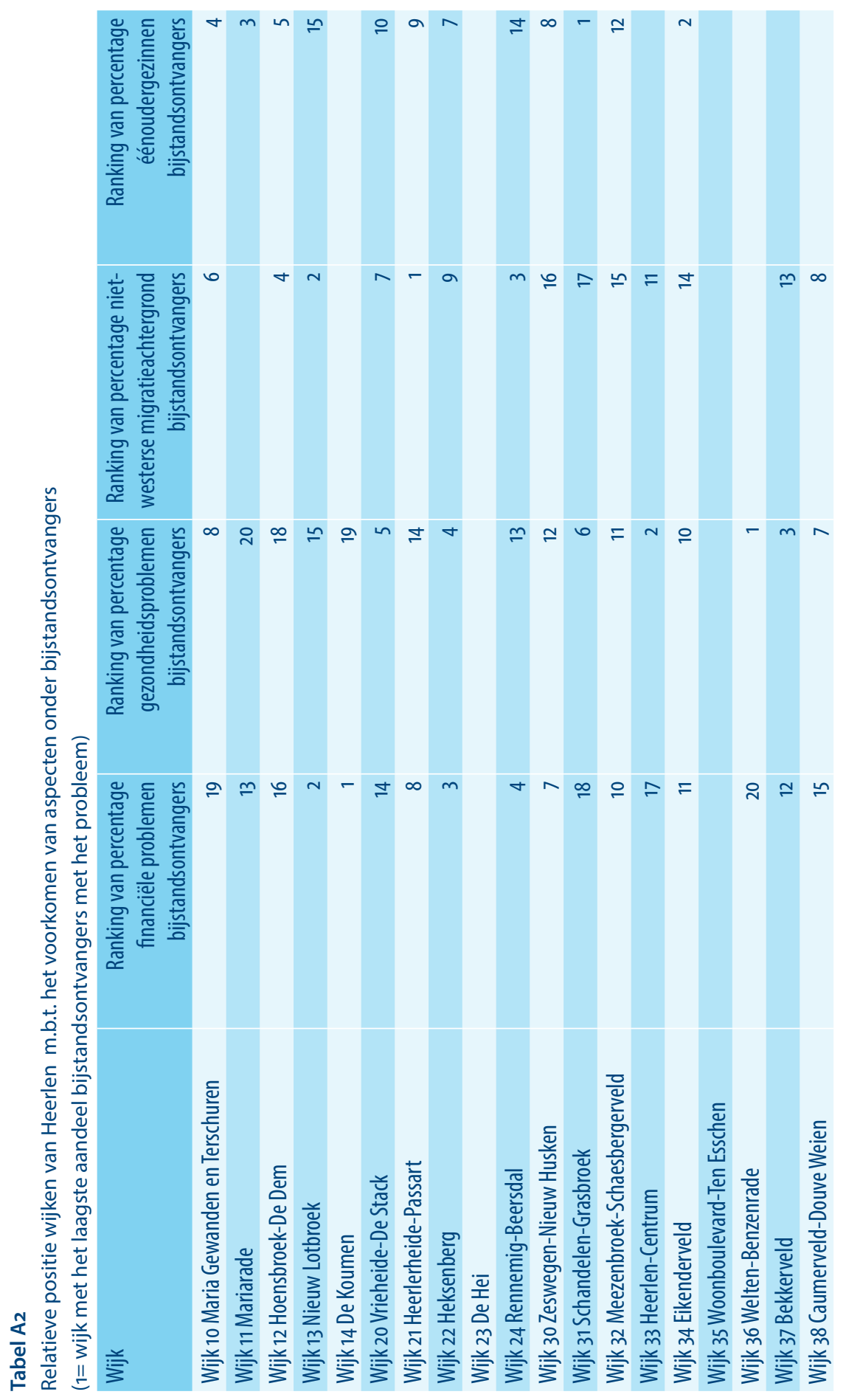




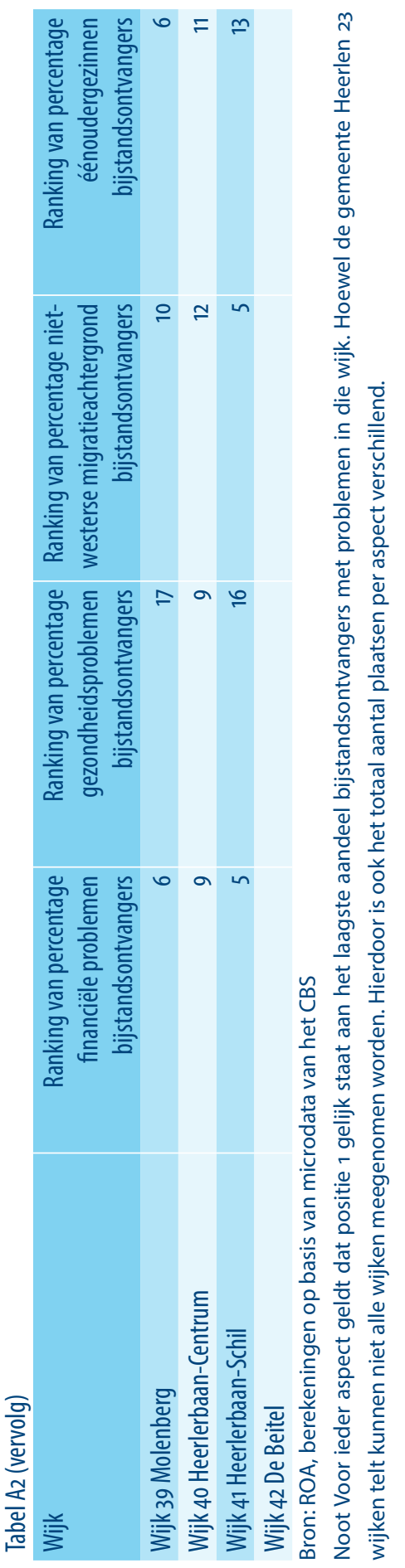

